\title{
System Dynamics Modelling of the Global Extraction, Supply, Price, Reserves, Resources and Environmental Losses of Mercury
}

\author{
Harald Ulrik Sverdrup • Anna Hulda Olafsdottir
}

Received: 17 March 2020 / Accepted: 13 July 2020 / Published online: 13 August 2020

(C) The Author(s) 2020

\begin{abstract}
How mercury flows from geological sources to society and to the environment was modelled for this study. The industrial dynamics of mercury was modelled and included in the integrated assessment model WORLD7. The simulated mercury losses were used as input for a simplified global model for environmental pollution. The outputs were analysed and used to assess mercury pollution amounts and supply to society. In fossil fuels, there are a potential stock of 2 million tons in coal and other hydrocarbons, and 450,000 tons of that could be released to the environment if the fossil fuels are all to be burned. Such release would potentially cause major environmental damage and a significant human health risk. The simulations suggest that environmental mercury flows may peak in 2025, and slowly decline as mercury gets immobilized in nature. The simulations show that the pollution from technical use is eliminated by
\end{abstract}

H. U. Sverdrup

Gameschool, Norway Inland University of Applied Sciences, Holsetgaten 31, NO-2315 Hamar, Norway

H. U. Sverdrup $(\bowtie) \cdot$ A. H. Olafsdottir

Industrial Engineering, University of Iceland, Hjarðarhagi 2-6, IS-107 Reykjavik, Iceland

e-mail: harald.sverdrup@inn.no

A. H. Olafsdottir

e-mail: annahulda@hi.is putting the 2013 Minimata Convention into effect, but that environmental pollution from fossil fuels combustion and from environmental re-emissions will remain a significant problem for the next decades.

Keywords System dynamics · Mercury · Supply · Sustainability $\cdot$ Environmental pollution

\section{Introduction}

Mercury is very toxic, even at extremely low exposures, and thus, its toxicity has always been an issue since antiquity (Scoullos 2001). It is important that as little as possible ends up in the environment (Tchounwou et al. 2012, EEA 2018). It is a rare element of the IIb group of the periodic system. Mercury has a silvery colour, is a semi-precious metal. It is a liquid between -39 and $+357{ }^{\circ} \mathrm{C}$. It has been known since antiquity and has always been considered as very special. It was used in medical substances, and in the past, this was a source of substantial damage for those that got to be treated with mercury compounds. It was the first antibiotic used against syphilis. One important use has been as a liquid solvent for extracting silver and gold from ores. It has been used in amalgam, most known for its use as a dental material from about 1800 to about 2000. Any dental or medical use has been outlawed in the EU by the Heavy Metal Convention (de Vries et al. 2004; de Vries and Bakker 1998; Bakker et al. 1998; EEA 2018). 
This has further lead to the Minamata Convention, ${ }^{1}$ signed in 2013, and globally effective of 2017.

Scientifically, the toxicity and extreme danger of mercury exposure are well researched and documented and have no room for any doubt (European Environmental Aagency 2018; United States Environment Protection Agency 2020b). But old myths are hard to kill, and some simply deny every risk and refuse to change as many researchers can attest to (Berlin 1979; Bakker et al. 1998; Hansson 1986; 1989a,b, 1998; Kotter 2014; Kegan and LaskowLahey 2014). One such urban myth is that metallic mercury is chemically inert in the human body and thus harmless to humans; all the literature states the opposite clearly (Axelrad et al. 2007; Hansson 1986; 1989a,b; Berlin 1979; Bernadin et al. 1981; Clarkson 1979; Clarkson and Magos 2006; Hylander et al. 2005; Bernhoft 2012; Ekino et al. 2007; Benford et al. 2012; Bellinger 2005; Jensen and Ruzickova 2006; EEA 2018).

During the period 2000-2010, all mercury was phased out in Europe from all use, because of the great toxicity (EU Commission 2018; European Parliament 2017, 2018, ; for the Heavy Metal Convention, see de Vries et al. 2004 and EU Comission 2018). In Europe, mercury can only be legally used with a public authority permit, and only in high-level controlled laboratories (EC 2017; European Environmental Agency 2018; UNEP 2013a,b,c, 2019; the Minamata Convention , see EC 2017). The efforts have resulted in a substantial decline in emissions to the environment (Zhang et al. 2015). The rest of the world is slowly following, delayed, mainly because of less environmental professionalism in governance and lower levels of political responsibility for public health. In the USA, mercury is still used carelessly in certain vaccines and non-prescription drugs (Danasekaran et al. 2013, Jensen and Ruzickova 2006). Mercury was banned from paint for indoor use in the USA as late as 1991.

In antiquity, the large producers were Spain, Italy, and Slovenia, but in these countries, all mines have been closed during the late 1990s. Later, new mercury mines

\footnotetext{
${ }^{1}$ It is, a legally binding agreement known as the Minamata Convention on Mercury, which was agreed to by 147 countries, ratified and implemented since 2013. The Minamata Convention will cause ratifying countries to phase out - and, by 2020, to ban the use of mercury in a range of consumer items, including batteries, light bulbs, medical devices, dental fillings and vaccines, as well as address issues with pollution from small-scale gold mining and coal-fired power plants.
}

were opened in the Americas and in East Asia and some are still active. The main mercury producer is at present is China with 3000 tons per year, Mexico with 300 tons per year, and Kyrgyzstan, Peru and Tajikistan with 30 tons per year each, all from primary mining of cinnabar. In 2003, secondary mercury sources were contributing about $5 \%$ of the production. The main uses of mercury are in thermostats $47 \%$, switches $24 \%$, dental amalgam $21 \%$, thermometers $5 \%$ and other $2 \%$. There are good substitutes for all of those uses, and society will do fine with no mercury available. Figure 1 shows the mercury production (a) and market price (b) 1850-2015 according to the USGS (2019a, b) as plotted by the authors. The price crashed because of vanishing European mercury demand, making the European mercury mines in Spain, Italy and Slovenia close.

\section{Objectives}

The main objectives of this study are the following: establish a basic global model for mercury and to include it in the WORLD7 integrated assessment model, and make assessment of the mercury supply dynamics to society, before and after the introduction of the 1999 Århus Heavy Metal Protocol and the 2013 Minimata Convention and to make impacts assessments for mercury environmental pollution as a result of the different pathways of mercury from geological sources to the environment. Associated with this was to find data for the global stocks of mercury in geological deposits of metals ore and as contamination in fossil fuels stocks.

\section{Methods}

\subsection{Systems Analysis and System Dynamics}

The methodology used here uses system analysis for conceptualization, as the preparation for building a simulation model using the STELLA software. The main standard methods of system analysis and system dynamics modelling are used (Albin 1997; Forrester 1961, 1969, 1971; Meadows et al. 1972; 1992, 2005; Roberts et al. 1982; Senge 1990; Haraldsson and Sverdrup 2005; Haraldsson et al. 2006; Sverdrup et al. 2018). We analyse the system using stock-and-flow charts and causal loop diagrams. The learning loop is the adaptive learning procedure followed in our studies 


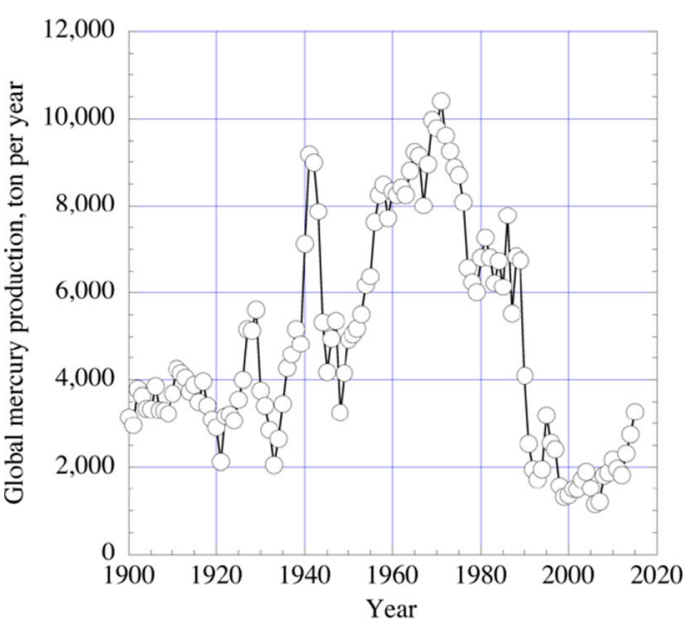

a) Production

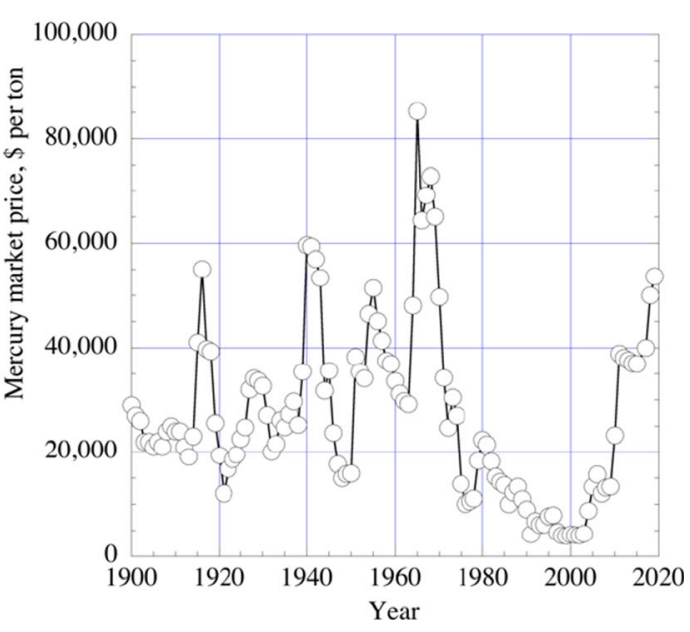

b) Price

Fig. 1 The mercury production (a) and market price (b) 1850-2015 according to data adopted from the USGS (2019a, b) by the authors

(Senge 1990; Senge et al. 2008). The entering of the code follows from the causal loop diagrams and flow charts developed in the conceptualization stage. The differential equations resulting from the flow charts and the causal loop diagrams will be numerically solved using the STELLA® modelling environment (Sterman 2000; Haraldsson and Sverdrup 2005; Sverdrup et al. 2018). To the largest degree, all constants and settings have been based on observed system parameters, in order to eliminate the need for calibration. The WORLD7 model is not using state data or time series for calibrating (Hirschnitz-Garbers et al. 2015; 2017, 2018, Koca et al. 2017; Lorenz et al. 2017; Sverdrup and Koca 2017, 2018; Sverdrup and Olafsdottir 2019a, b; Sverdrup et al. 2019). The WORLD7 model is operated as one concerted whole, where everything runs simultaneously.

\subsection{Sustainability Versus Unsustainability}

In industrial use of metals and materials, we look at stocks-in-use per capita as a measure of utility gained from the resource. Supply per capita per year can be used to evaluate if the supply is sufficient to maintain the stock per capita in order to compensate for losses, and if there is something left for growth. For mercury use, the stock per capita should go down as fast as possible. In environmental context, the stocks-in-use-for pollution per capita should be as low as possible. When the supply rate per capita per year to the environment is lower than the immobilization and capture, then the environmental burden per capita goes down. On the global scale, mercury is sequestered from the environment by sedimentation into anoxic sediments in deep lakes and the oceans. There it is long term bound as sulphide.

\subsection{Resource Estimation}

The method has several steps: (1) establish how much metal is present, (2) sort up the totalmercury resource in quality classes, based on extraction costs and process yields, (3) establish the fraction of the present mercury that will be ultimately recovered, based on mercury ore grade cut-off limit and extraction yield estimates.

\subsection{Basic Principles Applied in Modelling}

Supply is composed of both primary production, secondary extraction as a by-product of the production of other metals and recycling of used material. From mass balance, we have that the supply is equal to the production plus recycling (AMAP/UNEP 2013, 2015, Bergan et al. 1999; Sverdrup et al. 2019):

$$
\begin{aligned}
\text { production }+ \text { recycling }= & \text { accumulation } \\
& + \text { recycling } \\
& + \text { permanent losses }
\end{aligned}
$$

This is the same accumulation in the system plus recycling plus losses. Note carefully that recycling appears on both sides. It can mathematically be cancelled out of the equation. It expands the total flux going 
through the system, without demanding new primary material to be added. Recycling rates could be considerably increased for many metals based on governmental policies, but those policies need to be set in place (Sverdrup et al. 2017a).

\section{The WORLD7 Model}

The WORLD7 model has been quite useful and successful for studying the nexus of resource use, energy use, populations dynamics, international resource trade, production of prosperity in society and climate change. In an ongoing development process, more societal factors are being included in the model.

\subsection{The WORLD7 Model Framework}

The WORLD7 model is an integrated assessment model, designed to describe major parts of society including mass flows, economy, natural environment, resources and people (Hirschnitz-Garbers et al. 2015, 2017, 2018; Koca et al. 2017; Sverdrup und Koca 2017, 2018; Sverdrup and Olafsdottir 2019a, b; Sverdrup et al. 2018, 2019). The purpose of the WORLD7 model is to link resource use, the global economy, human development, industrial dynamics, public health and environmental impacts into one large structure, in order to assess global sustainability development. It includes several interlinked sub-modules including population dynamics, the economy, industrial and agricultural dynamics, natural resource use and the stability of societies (Sverdrup et al. 2019). The WORLD7 model was built using system analysis and system dynamics modelling (Forrester 1961, 1969, 1971; Meadows et al. 1972, 1974, 1992, 2005; Roberts et al. 1982; Senge 1990; Bossel 1998; Haraldsson 2004; Haraldsson and Sverdrup 2005; Haraldsson et al. 2006; Sverdrup et al. 2018).

The world system was analysed using stock-andflow charts and causal loop diagram, and a learning loop was used as the adaptive learning procedure (Senge 1990; Kim 1992; Senge et al. 2008). This approach in model development is best suited to mechanistic models that are based on cause and effect. The WORLD7 model is not calibrated by adjusting key parameters fitting it to systems output data (Lorenz et al. 2017; Sverdrup et al. 2018, 2019; Sverdrup and Olafsdottir 2019a, b; Sverdrup 2019). The underlying system causal linkages and the mass balances lead to equations that are parameterized on independent system properties, initial states and boundary conditions (Sverdrup et al. 2019). The details on how the model is constructed can be found in the background publications (Sverdrup et al. 2014, 2015, 2017a,b, 2018, 2019; Sverdrup and Ragnarsdottir 2014; Sverdrup and Olafsdottir 2018; Olafsdottir and Sverdrup 2018, 2019; Sverdrup 2017).

The WORLD7 model operates on an aggregated global scale. The WORLD7 model operates in normal mode with a daily time-step (1/365), but uses yearly printouts of results. Each iteration of the WORLD7 model and its sub-models was programmed in STELLA Architect software (Sverdrup et al. 2014, 2015, 2017a,b, 2018, 2019; Sverdrup and Ragnarsdottir 2014; Sverdrup and Olafsdottir 2018; Olafsdottir and Sverdrup 2018, 2019; Sverdrup 2017, 2019).

\subsection{The Mercury Module in WORLD7}

The mercury model was included as a submodule in the WORLD7 model (Sverdrup 2019, Sverdrup et al. 2019). For more information on the WORLD7 model, please check the earlier works published (Koca et al. 2017; Sverdrup et al. 2018, 2019). The following sectors describe some of the underlying assumptions for the mercury submodule and the basic structure.

\subsubsection{Basic Layout for the Mercury Module}

Figure 2 shows the flowchart for mercury that describes the basic layout of the model as laid out in Fig. 3 inside WORLD7. The model has two parts. The industrial dynamics in the upper part with extraction from geological reserves and resources, mining and refining and sales to the metal market. The path to mercury stockin-use is via the market. They are undifferentiated in the model. The stock-in-use are either lost during use to diffuse losses or to waste stocks. Any human being with mercury can be directly exposed and contaminated during use. For a period, mercury was used in pesticides and seed conservation, and as a preservative in paint, including paint for indoor use. Those practices have again stopped, but not without resistance and delays. The use of mercury in thermometers and barometers has largely stopped in Europe. There are some phosphorus deposits that have traces of mercury, and this all contribute to the general global background exposure. More important, sewage sludge can be used as fertilizer, and if 


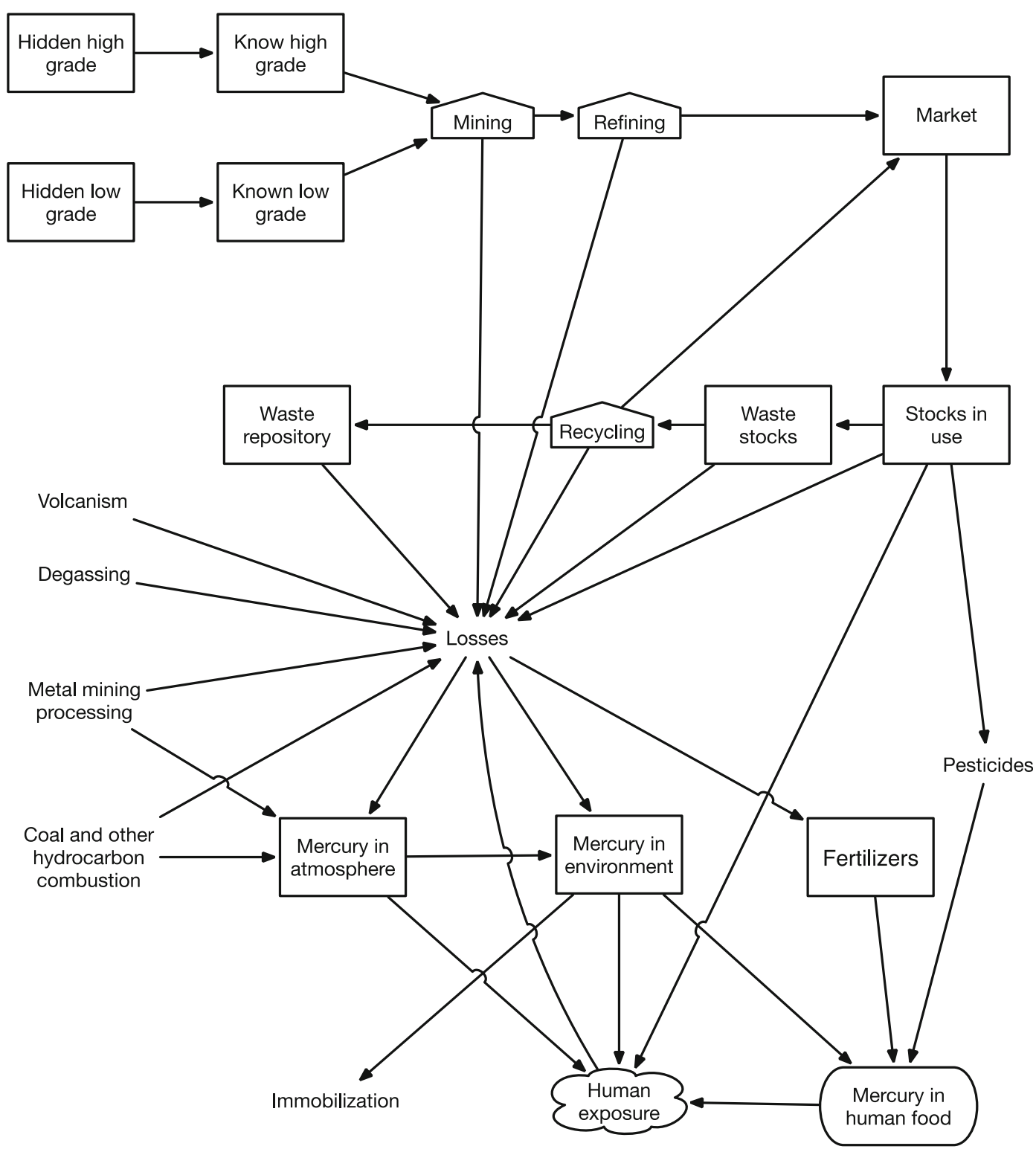

Fig. 2 The flowchart shows the basic layout of the model as laid out in Fig. 3. The mercury model sits inside the WORLD7 Integrated Assessment Model. The mercury sub-model has two parts. The industrial dynamics in the upper part with extraction from

it is not screened properly, mercury pollution may find its way into the food production.

\subsubsection{Volcanic Emissions}

The volcanic emissions are set at a basic constant rate (Nriagu 1994; Nriagu and Becker 2003; Driscoll et al. 2013); but with some random variations overlaid on the trend. The Hg emissions from fossil fuels are dependent geological reserves and resources, and the environmental part below. A main route for mercury into agricultural fertilizer is with urban sewage sludge. Historically, mercury was earlier used in pesticides and fungicides

on coal combustion, and the mercury mining emissions proportional with copper and zinc mining (Telmer and Veiga 2009). re-deposition of volatilised mercury accounts for $32 \%$ of the ecosystem input in the USA (Bergan et al. 1999; Kerfoot et al. 2000, 2004). The revolatilisation is assumed to be similar on a global level. The volatilisation takes place from the atmosphere and global bioavailable stock. It is caused by evaporisation of metallic mercury in the environment and re-emissions 


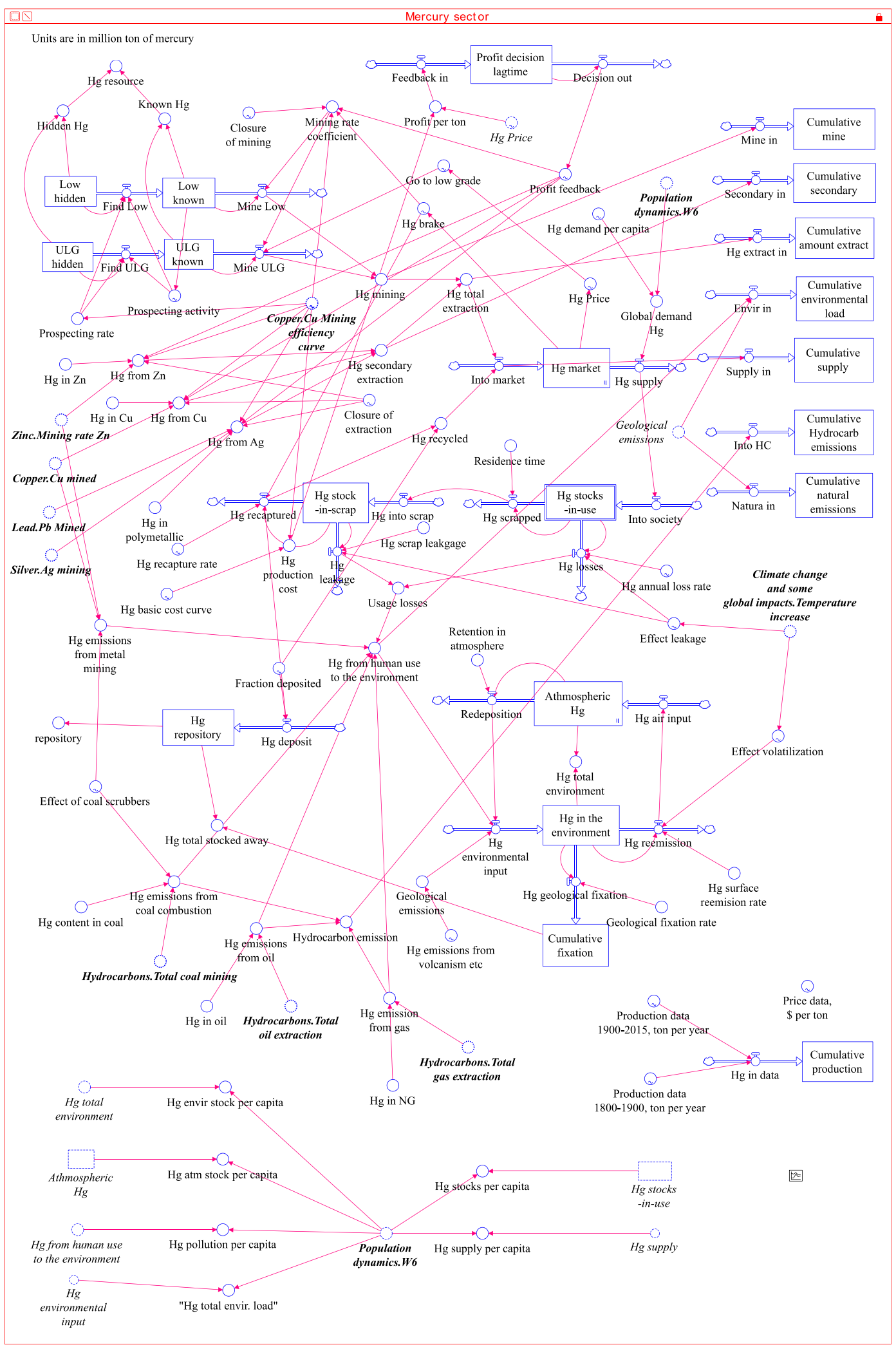

Fig. 3 The mercury unit inside WORLD7 in the STELLA Architect expression 
of methylmercury (Krabbenhoft and Schuster 2002; Krabbenhoft and Sunderland 2013). Methylisation occurs through microorganisms in the soil (Meili et al. 2001, 2003) as well as in ocean sediments. Methyl mercury is neurotoxic, human immune-depressive, volatile and mobile in the environment (Sverdrup 2001; Sverdrup and Ashmore 2001; Hong et al. 2012; Bernhoft 2012, Swearengin 2008).

\subsubsection{Mercury Toxicity}

Toxic metals seem to have their own cycles in nature and society, but may to some degree associate with airborne particles. Figure 4 a shows the dose-response curves for mercury. Figure $4 \mathrm{~b}$ presents an example of a simulation of how mercury deposition can be transferred to content in freshwater fish (Sverdrup and Ashmore 2001; Meili et al. 2001, 2003; Tchounwou et al. 2012). Selenium is antagonistic to mercury by immobilizing it. Sulphide forms a trap for mercury in anoxic environments. Inputs to the toxicology model comes from different parts of the WORLD7 system. The toxic metals are derived in the model from the production and use of cadmium, mercury, copper, zinc and lead (Sverdrup 2001; Sverdrup and Ashmore 2001, Meili et al. 2001, 2003, Schloss 2019, State Council of the People's Republic of China 2013, Tian et al., 2010, 2015). Air pollution is derived from combustion of fossil fuels, in particular for mercury. Organic chemicals are derived

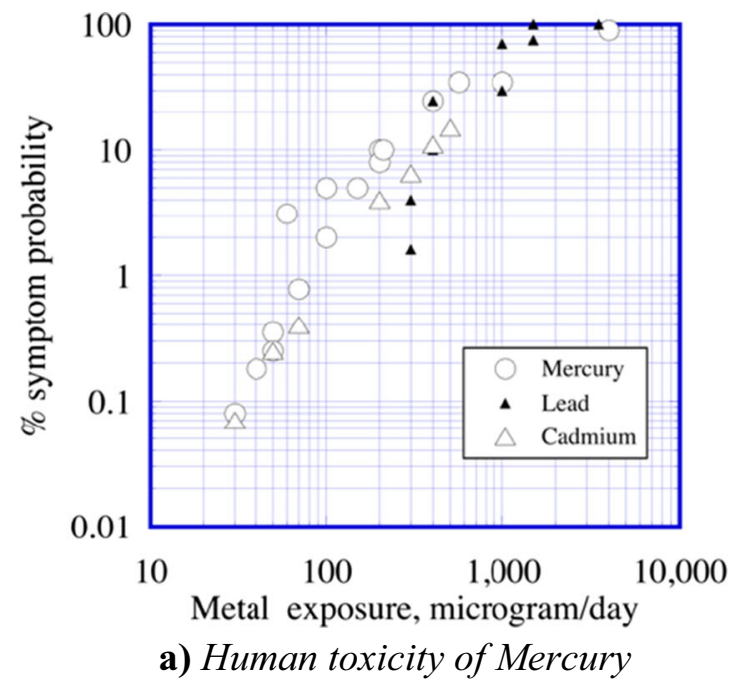

Fig. 4 a The dose-response curves for mercury, lead, and cadmium exposure in humans. b An example of a simulation of how mercury deposition can be transferred to content in freshwater fish. The diagrams were developed from simulations and assessments from coke production, production of fossil fuels and natural gas through leakages. Mercury is both an endocrine disruptor, has effect on the central nerve system and the immune system. This is not seen as a significant problem at the present, but this may be a result of lack of understanding of the great toxicity of mercury. As much domestic use of mercury has declined, the content of mercury in public sewage may be expected to decrease in the long-term perspective. At present, the global background is elevated because of human activities. The waste is either lost, immobilized or recycled. From recycling some material is either resold to the market or after 2010, more probably put into safe storage. The United States Environmental Protection Agency (US EPA) and the California Department of Public Health (CDPH) regulate mercury levels in drinking water (Toxicological Profile for Mercury 1999). The current State and Federal Maximum Contaminant Level (MCL) for inorganic mercury is $2 \mu \mathrm{g} / \mathrm{l}$ (GAMA 2009).

Losses into the world from the industrial cycles in society are added to emissions from the global volcanism, from degassing from natural gas production, in natural gas emissions from geothermal venting and from re-emissions from contaminated ecosystems and soils. The lower part in the drawing is the environmental part. Mercury alternates between being volatile in the atmosphere and sits as adsorbed in the ecosystems (Driscoll et al. 2013; Smith-Dowey et al. 2010). Mercury in society originates from several sources and this is

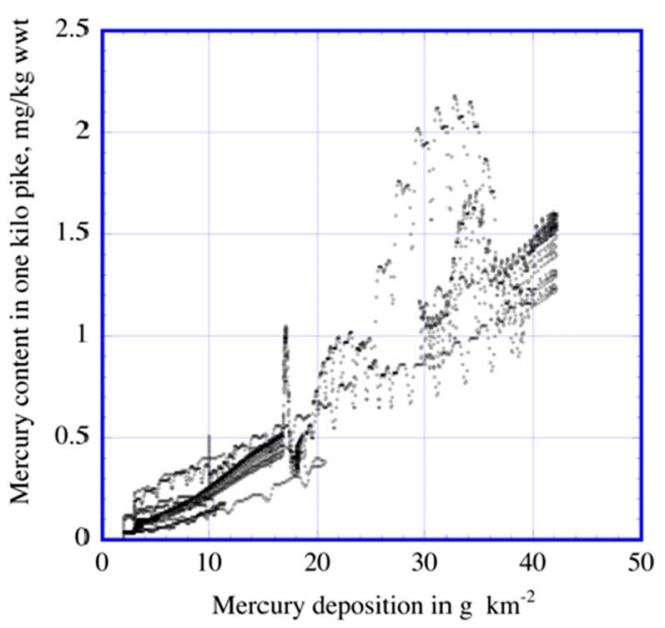

b) Mercury to fish in fresh water lakes

made in earlier work by the authors (Sverdrup et al. 1990, 1998; Sverdrup 2001; Sverdrup and Ashmore 2001; Bakker et al. 1998; de Vries and Bakker 1998, de Vries et al. 2004 ) 
reflected in the model. Human exposure can come from contaminated foods (fish that live for a long time, vegetables from polluted and contaminated soils), antibacterial additives, polluted air and from dental use of mercury (Amorim et al. 2000, Bakir et al. 1973, Braid 2007, Buchet et al. 1980, Cherian et al. 1978, Clewell and Clewell 2008, Camner et al. 1979; Clifton 2007, Cox 1981; Ehrlich 1910a,b, Enestrøm, 1989, Friberg 1951, Friberg 1969, Gerson et al. 2019, Gore et al. 2015, Gregor et al. 1999, Hansson 1989a,b,c, Hu et al. 2018, Ibrahim et al. 2006, Janishankar et al. 2014, Lanfor and Ferner 1999, Lauwerys ans Buchet 1973, Lee et al. 2017, Lelieweld et al. 2015, Stock 1926; 1934a, b, 1935, Levy 1995a,b; Mayer 1975; Ngim et al. 1992; Pelletier et al. 1986, Perry and Erlanger 1974, Pinheiro et al. 2008, Popescu et al. 1979, Rehman et al. 2018, Schwenk et al. 2009, Seifert and Neidert 1954, Streets et al. 2017, Sundseth et al. 2017, Svare et al. 1981, Vimercati et al. 2001, Vimy and Lorscheider 1985a, b; Vimy et al. 1986; Waldron 1983, Yokooet al. 2003, Zhao et al. 2006, Windham 2010) as well as domestic Mercury spills (Hansson 1986; GBD 2016; Hunter et al. 1940; Doherty 2003).

Limits for mercury in nature are available for a number of ecosystem components consistent with the UN/ ECE LRTAP Protocols, and the Minamata Convention. The substitute, the older WHO limits, based on older health and occupational standards, set for limits to human exposure. They all have in common that they have been significantly adjusted down as compared to older limits (EC 2017; European Environmental Agency 2018; UNEP 2013a,b,c, 2019).

\subsubsection{Sources of Mercury for Extraction and Pollution}

Mercury has been mined since antiquity, possibly as much as 250,000 tons may have been extracted until 1850 (Pacyna et al. 2010; Pirrone et al. 2010). Significant amounts of mercury originate from volcanic activities, such as venting and eruptions (Nriagu and Becker 2003, Amos et al. 2013). Degassing of natural gas also contributes mercury to the atmosphere. Much of the mercury can be re-volatilised from terrestrial ecosystems and from the ocean (Bergan et al. 1999). Data on the biogeochemical cycle of mercury was derived from the state-of-the-art literature (Brooks et al. 2007, Clewell and Clewell 2008, Cooke et al. 2009, Diaz 2013, Driscoll et al. 2013; Lamborg et al. 2002, Lindberg et al. 1998, Mann et al. 1996a,b, Meinert et al. 2016, Ninomiya et al. 1995, Pacyna et al. 2006, 2010; Pirrone et al. 2010; Rooney 2014, Selin 2009; Smith-Dowey et al. 2010; Sverdrup and Olafsdottir 2018, Sverdrup 2018, Sverdrup et al. 2014, 2015, 2017b, Sverdrup and Ragnarsdottir 2016, Streets et al. 2011; Zhang et al. 2015). The extractable part of the remaining global mercury resource was estimated to be ca 1.2 million tons (Table 2). Total URR of all times is probably about 1.5 million tons according to our assessment of the available data (USGS 2019). Mercury is rarer than silver. The price is lower, as the demand is smaller and declining because of legislation against its use. Mercury ore has contents ranging from 2.5 to $0.1 \%$ per weight in the ores used for extraction so far. The chlor-alkali process is used in the manufacture of chlorine, hydrogen and sodium hydroxide (caustic) solution (Castner-Kellner Process, Du et al. 2018) which used a lot of mercury in the past, but that has been substituted by other processes. During the last 40 years, smoke gas cleaning equipment has been installed in the chemical industry and on coal-fired powerplants in the industrialized world. A side effect of smoke gas cleaning is that it partially removes mercury in the flue gas. Likewise, in the last 20 years, smoke cleaning from crematories in the industrialized world has reduced mercury emissions from these.

Table 1 shows an overview of estimated amounts of mercury in geological deposits in $1000 \mathrm{BC}$ as estimated from the literature. Table 2 shows an overview of amounts of mercury in geological deposits in $1850 \mathrm{BC}$ compiled by the authors. Amounts are in ton mercury metal. The better mercury ore grades were all exhausted before 1850 and do no longer exist. Mercury extraction started probably around 1000 BC. In the deposits, mercury frequently occurs as native metal. Most common is natural mineral containing mercury is cinnabar, the mercury sulphide (HgS).

Table 2 shows an overview of amounts of mercury in geological deposits (see Pirrone et al. 2010 and Zhang et al. 2015 for a review of the literature on geological emissions). We suggest that about 200,000 tons of mercury had been extracted prior to 1850 by comparing Tables 1 and 2. The listed amounts in the tables are in ton mercury metal. Note that the amounts remaining in fossil fuel deposits are large and comparable in amounts to silver (Sverdrup et al. 2014). The total primary deposit is estimated to contain about 4.6 million tons of mercury and the total deposits about 4.9 million tons, but note that much of that is not extractable for technical use. The fraction of that resource which would be available for extraction is much smaller. 
Table 1 Overview of estimated amounts of mercury in deposits in $1000 \mathrm{BC}$. Metric ton mercury metal

\begin{tabular}{llrrrrr}
\hline Grade class & Mineral form & \multicolumn{2}{l}{ Contents, \% weight } & & \multicolumn{2}{c}{$\begin{array}{l}\text { Sum } \\
\text { metric ton }\end{array}$} \\
\cline { 3 - 4 } & & Average & Range & & \\
\hline Rich & Metallic & 35 & $50-20$ & & 1000 & Now exhausted \\
High & Metallic, Cinnabar & 12 & $20-5$ & 100,000 & Now exhausted \\
Low & Metallic, Cinnabar & 2.5 & $5-2$ & 500,000 & Mined now \\
Ultralow & Metallic, Zn, Cu, Cinnabar & 0.5 & $2-0.5$ & 800,000 & Mined now \\
Trace & Polymetallic, Cinnabar & 0.15 & $0.5-0.1$ & $1,440,000$ & Secondary \\
Rare & Polymetallic deposits & 0.03 & $<0.1$ & $2,005,000$ & Contamination \\
Sum & All deposits & & & $4,846,000$ & \\
\hline
\end{tabular}

Table 3 shows the initial values used at the beginning of the WORLD7 simulation in 1850 compiled by the authors. Table 4 shows occurrences of secondary mercury in some metal ores as compiled by the authors. The extractability of these resources depends on the mercury price and availability for extracting the mercury from ore residuals and smelting waste. The amounts listed are in ton of mercury. What cannot be extracted, will (to 80$90 \%$ ) be ending up as environmentally available pollution. Coal and hydrocarbon deposits contain as a whole, significant amounts of mercury. Table 5 shows an estimate of the mercury contained in fossil fuels and potential amounts available for release if it was all released by fuel combustion. The mercury removal yield relates to cleaning systems applied to exhaust and to fuel production. Not all of these hydrocarbons will be extracted; we estimate the amount in the hydrocarbons likely to be extracted to amounts have been listed in Table 5. Note that the amounts contained in fossil fuel deposits are larger than those identified in ore deposits. All the known deposits that are evaluated as not interesting for extraction have been omitted. All of this mercury will become potential pollution if all the fossil fuels they are contained in are burned (Rytuba 2002, 2003). This stock of mercury is at present to not feasible for extraction to mercury metal because of the low concentration in the substrate (Fig. 5).

\section{Results}

The research results are categorised according to the objectives set up for this study earlier.

Table 2 Overview of amounts of mercury in geological deposits at the beginning of the WORLD7 simulation in 1850. Amounts are in ton mercury metal

\begin{tabular}{|c|c|c|c|c|c|c|c|}
\hline \multirow[t]{2}{*}{ Grade } & \multirow[t]{2}{*}{ Mineral form } & \multicolumn{2}{|c|}{ Contents, $\%$} & \multirow{2}{*}{$\begin{array}{l}\text { Yield } \\
\%\end{array}$} & \multirow{2}{*}{$\begin{array}{l}\text { Known } \\
\text { ton of mercury }\end{array}$} & \multirow[t]{2}{*}{ Hidden } & \multirow[t]{2}{*}{ Sum } \\
\hline & & Mean & Range & & & & \\
\hline Rich & Metallic & 50 & $70-25$ & $90-99$ & Exhausted & Exhausted & Exhausted \\
\hline High & Metallic, Cinnabar & 15 & $25-5$ & $90-99$ & Exhausted & Exhausted & Exhausted \\
\hline Low & Cinnabar & 2.5 & $5-2$ & $90-95$ & 100,000 & 300,000 & 400,000 \\
\hline Ultralow & $\mathrm{Zn}, \mathrm{Cu}, \mathrm{Ag}, \mathrm{Cinnabar}$ & 0.5 & $2-0.5$ & $50-85$ & 100,000 & 700,000 & 800,000 \\
\hline Trace & $\mathrm{Zn}, \mathrm{Cu}, \mathrm{Ag}$, Cinnabar & 0.15 & $0.5-0.1$ & $20-65$ & 40,000 & $1,400,000$ & $1,440,000$ \\
\hline Rare & Polymetallic ores & 0.03 & $<0.1$ & $0-30$ & 5000 & $2,000,000$ & $2,005,000$ \\
\hline Primary deposit & & & & & & & $4,645,000$ \\
\hline Secondary & & & & & & & 230,500 \\
\hline Sum & & & & & & & $4,875,500$ \\
\hline
\end{tabular}


Table 3 Input values for WORLD7 model. Initial stock values (for 1850), based on extractable amounts (million ton)

\begin{tabular}{|c|c|c|c|c|}
\hline Stock & Total stocks & Total extractable & Hidden amount & Known amount \\
\hline Low-grade ore & & 0.4 & 0.3 & 0.1 \\
\hline Ultralow-grade ore & & 0.8 & 0.7 & 0.1 \\
\hline Sum in ore & & 1.2 & 1.0 & 0.2 \\
\hline In use in society & & & & 0.1 \\
\hline In scrap & & & & 0.06 \\
\hline In the environment & & & & 0.1 \\
\hline Atmospheric content & & & & 0.028 \\
\hline Sum in total & 2.888 & 1.2 & 1.0 & 0.688 \\
\hline
\end{tabular}

\subsection{Model: Establish a Basic Global Model for Mercury}

The mercury module is causally linked to variables in other modules and it provides a mercury supply and mercury market price for the industrial dynamics section of the WORLD7 model. The mercury module also generates reliable estimates of mercury losses to nature that are used as inputs to the environmental module and to the public mortality module in WORLD7. The graph to the left on Fig. 6 shows simulation outputs compared recorded history. The graph to the right on Fig. 6 shows the cumulative extracted amount, versus the recorded cumulative amount from 1850 to 2015 . Since the curves fit well with the historic data, it increases likelihood that the predicted future scenarios hold for the assumptions made.

The graph to the left in Fig. 7 shows different sources of mercury production. Mercury originates from primary mining in Spain, Slovenia, China and South America. The mines in Europe were closed in 2002. The graph to the right on Fig. 7 shows the simulation of the market price

Table 4 Occurrences of secondary mercury in some metal ores. The extractability of these resources depends on the mercury price and availability for extracting the mercury from ore residuals and in the graph to the right. The dotted line represents the observed data on price as seen by the USGS (2019). The market has not been a free and dynamic market at all times. The military in several countries has had their strategic stocks of mercury and influenced the trade in the past. Before 1850, humans had already extracted about 250,000 ton of mercury, of this 150,000 ton remained in stocks-in-use and in waste by 1850 . We have assumed that 100,000 ton of mercury would be in the environment in 1850 (see Table 3). After the banning of mercury use in Europe through the protocol and the Convention, the mercury market disappeared. Only a very specialized technical market will remain after 2020, and then it will only be available at a high cost, covering all associated costs.

\subsection{Supply and Recycling: Assessment of the Mercury Supply to Society}

To assess the long-term sustainability of mercury, it is beneficial to look at stocks-in-use per capita to measure

smelting waste. Amounts are in ton. What cannot be extracted, will (to $80-90 \%$ ) be ending up as environmentally available pollution (Sangster 1990; Schwartz 1997, 2002; Selin 2009)

\begin{tabular}{lrrrrl}
\hline Source metal & $\begin{array}{l}\text { Source metal, } \\
\text { million ton }\end{array}$ & $\begin{array}{l}\text { ppm } \\
\text { content }\end{array}$ & $\begin{array}{l}\text { Mining } \\
\text { yield, } \%\end{array}$ & Mercury, ton & Source \\
\hline Silver & 3.5 & 12 & $0-30$ & 42 & Rytuba 2002, 2003; Schwartz 1997, 2008 \\
Copper & 4030 & 18 & $0-30$ & 72,540 & Rytuba 2002, 2003; Schwartz, 1997, 2008; Kerfoot et al. 2004 \\
Zinc & 2676 & 50 & $40-60$ & 133,800 & $\begin{array}{l}\text { Rytuba 2002, 2003; Sangster 1990; Schwartz 1997, 2008; } \\
\text { Kerfoot et al. 2004 }\end{array}$ \\
Lead & 3015 & 8 & $0-30$ & 24,120 & Rytuba 2002, 2003; Schwartz 1997, 2008; Kerfoot et al. 2000, 2004 \\
Polymetallic & 1000 & 20 & $30-50$ & 20,000 & Kerfoot et al. 2000, 2004; Schwartz 2008 \\
Sum & & & & & \\
\hline
\end{tabular}


Table 5 Mercury in fossil fuels and potential amounts available for release of it was all released by fuel combustion. The mercury removal yield relates to cleaning systems applied to exhaust and to

\begin{tabular}{lrrrrrr}
\hline Source & $\begin{array}{l}\text { Source, } \\
\text { million ton }\end{array}$ & $\begin{array}{l}\text { Hg content, and } \\
\text { range PPM }\end{array}$ & $\begin{array}{l}\text { Estimate of } \\
\text { mercury } \\
\text { amount, ton }\end{array}$ & Range, ton mercury & $\begin{array}{l}\text { Mercury } \\
\text { removal } \\
\text { yield, } \%\end{array}$ & $\begin{array}{l}\text { Released to nature } \\
\text { if burned, ton }\end{array}$ \\
\hline Oil & 690,000 & $0.2 ; 0.1-1$ & 138,000 & $70,000-700,000$ & 85 & 21,000 \\
Gas & 530,000 & $0.2 ; 0.1-1$ & 106,000 & $50,000-530,000$ & 70 & 32,000 \\
Coal & $2,500,000$ & $0.8 ; 0.5-5$ & $2,000,000$ & $1,300,000-5000,000$ & 400,000 \\
Sum & $3,620,000$ & & $2,244,000$ & $1,420,000-6,230,000$ & 453,000 \\
\hline
\end{tabular}

fuels production (Mojammal et al. 2019; Bingham 1990; Selin 2009; Wilhelm 2001; Wilhelm et al. 2007; Wu et al. 2017) utility gained from the resource. Supply per capita per year is a beneficial measurement to use to evaluate if the supply is sufficient to maintain the stock per capita in order to compensate for losses for most metals but in the case of mercury, the goal is to use less. The graph to the left on Fig. 8 shows the stock in use per person, and the graph on the right shows the simulation of demand, total extraction, primary mining, secondary mining and recycled. Part of the recycling for mercury is taken aside and immobilized, removed from circulation. It is evident from the graph that a paradigm shift occurred in about 1994 when mercury supply and demand in principle collapsed. Then mercury use in thermometers, switches and dental amalgams stopped in Europe. Figure 9 shows aspects of production of mercury in terms of where it comes from, coal, oil, gas, from mining and natural emissions. Eventually, everything ends up in the

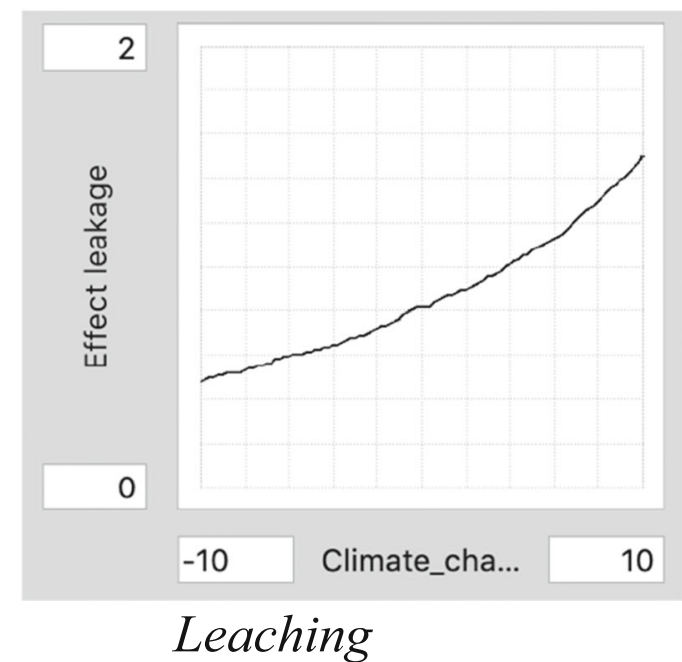

Fig. 5 The temperature dependence of mercury leaching from waste and stock in use and for re-emission of environmental mercury as a function of temperature change in ${ }^{\circ} \mathrm{C}$. The climate environment. Only natural emissions are outside human control.

\subsection{Pollution: Make Impacts Assessments for Mercury Pollution}

Mercury pollution into the world from the industrial cycles in society is added to emissions from the global volcanism, from degassing from natural gas production, in natural gas emissions from geothermal venting and from re-emissions from contaminated ecosystems and soils. On the global scale, mercury is sequestered from the environment by sedimentation into deep anoxic sediments in deep lakes and the oceans. There it is bound as mercury sulphide, a nearly insoluble compound in nature. Mercury will prevail long in the environment after that due to mercury re-volatilisation and

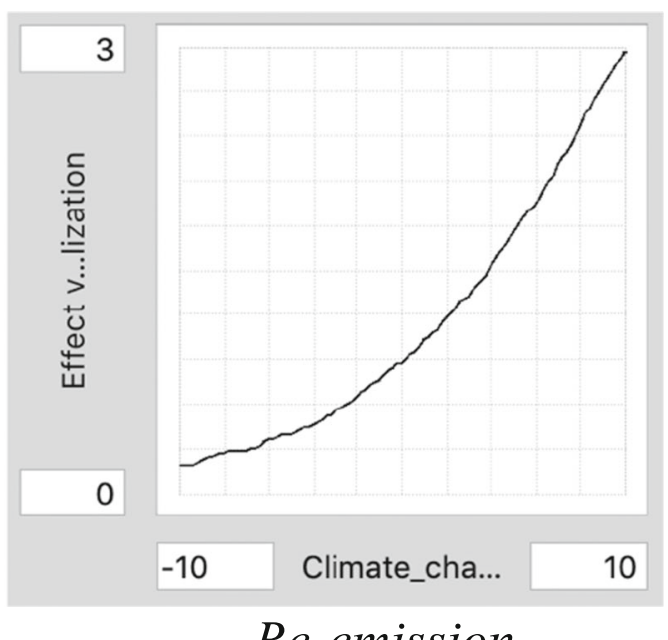

change is in degrees Celsius and derived from the climate model inside WORLD7. Leaching. Re-emission 


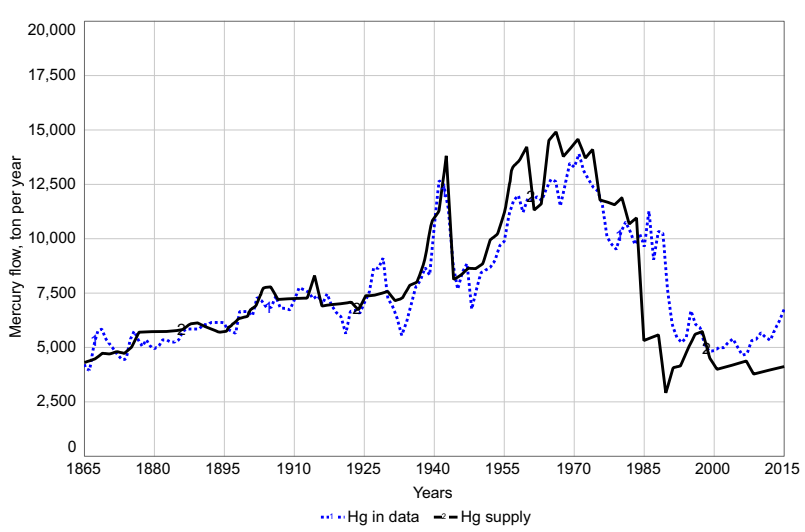

Fig. 6 (left) Testing the WORLD7 model simulation of mercury extraction on the recorded history of mercury extraction. (right) The cumulative extracted amount mercury, versus the recorded

the increased speed of mercury transformations caused by temperature increases from climate change.

When making the environments assessment, the stocks-in-use-for pollution per capita should be as low as possible. When mercury stocks in the environment go down (after 2025), we have a measure of environmental success. The graph to the left on Fig. 10 shows the simulated total mercury environmental input in ton per year, and the mercury stock in the environment and the mercury stock in the atmosphere. Mercury stays in the environment for a long time once it has arrived there (Bergan et al. 1999; Driscoll et al. 2013). The inputs to the environment seem to peak in the period 2040 and then decline from 2045 towards 2100 . The graph to the right in Fig. 10 shows the environmental stock per person, the atmospheric stock per person and the supply

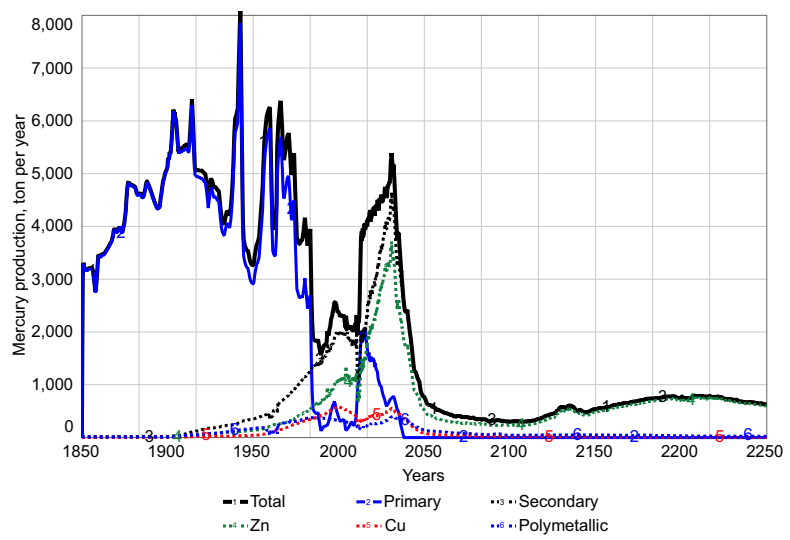

Fig. 7 (left) Simulation of the sources of the global mercury production. Mercury originates from primary mining in Spain, Slovenia, China and South America. The mines in Europe were

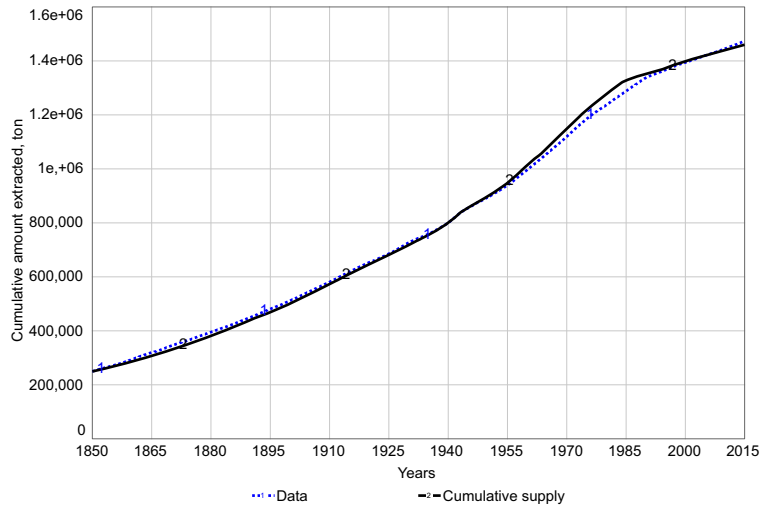

cumulative amount of mercury from 1850 to 2015. It appears that the history is well recreated with no significant bias in the results

per person per year, as well as the total environmental input, both anthropogenic and geological. This shows how the stocks in the environment peaked in 1920, and have steadily declined since.

The graph on the left in Fig. 11 shows geological, primary and secondary pollution effects. Looking at the primary and the secondary effects, it is clear that the secondary effects peak about 60 years later, indicating that even though primary pollution is well regulated, the effects will be present long after. The graph on the right in Fig. 11 shows mercury pollution divided into sectors, from fossil fuels, metal mining, geological and society. The natural geological mercury pollution is the only one that is not controllable, and the mercury pollution from the fossil fuels and from metal smelting peaks around 2015. The environmental pollution from technical use of mercury declined

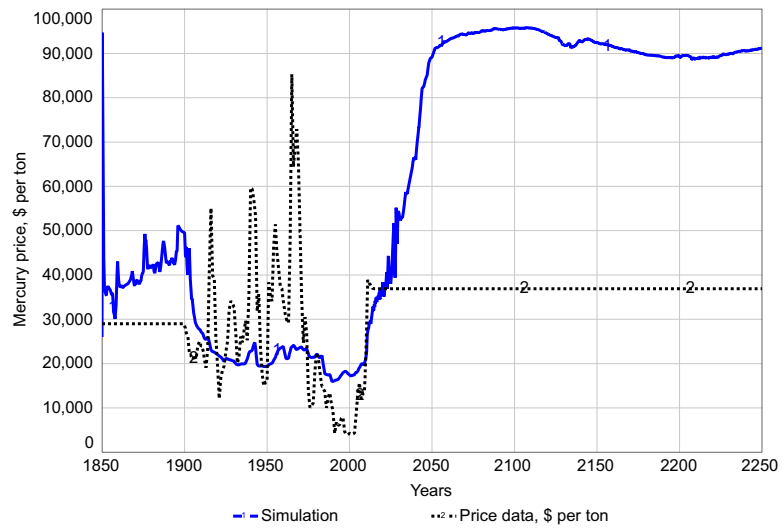

closed in 2002. (right) The simulation of the market price. The dotted line represents the observed data on price as seen by the USGS (2019), given as a dotted line 

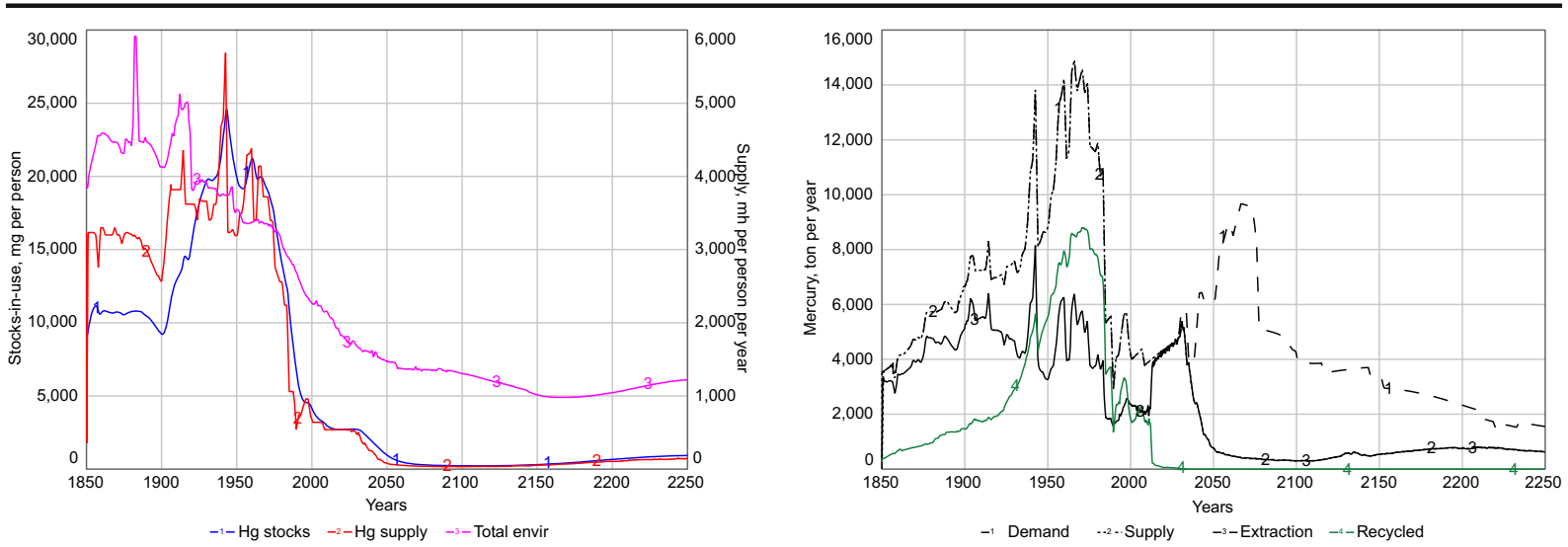

Fig. 8 (left) The stock in use per person and supply in mg per person per year. (right) The simulated development of the simulation of demand, total extraction, primary mining, secondary mining and recycled mercury

after 1990, and around 2000, mercury emissions from fossil fuel combustion became the largest source of mercury to the environment. After the year 1998, emissions from fossil fuels combustion will be the largest source of mercury to the environment. It is visible that the environmental input continues from geological sources and from re-emission of old pollution still stored in the environment.

In 2025, we have a paradigms shift. Then the secondary re-emission of mercury will become larger than the primary emissions. Note that in the simulation, the effect of climate change was considered. With increased temperatures, the emission rate will increase the speed of mercury circulations in the environment. The mercury pollution will reach higher concentrations, but decline faster. Eventually, the mercury gets sequestered into the sediments of the sea and lakes, by precipitation as mercury sulphide. Without climate change, the red line in the left graph in Fig. 11 would be much lower.

\section{Validation}

Even though the mercury model presented is relatively a simple sub-model within the framework of the WORLD7 model, the output indicates that the main dynamics have been captured. The outputs reconstruct the industrial ecology of mercury from 1850 to 2015 , and from that, we conclude that the model is a valid assessment tool and useful to look at plausible future scenarios based on "business as usual" and to compare that with other scenarios. Figures 6 and 7 show simulation output compared to observed data.
Fig. 9 Aspects of production of mercury, quantifying the amounts from coal, oil, gas, mining, and geological activity

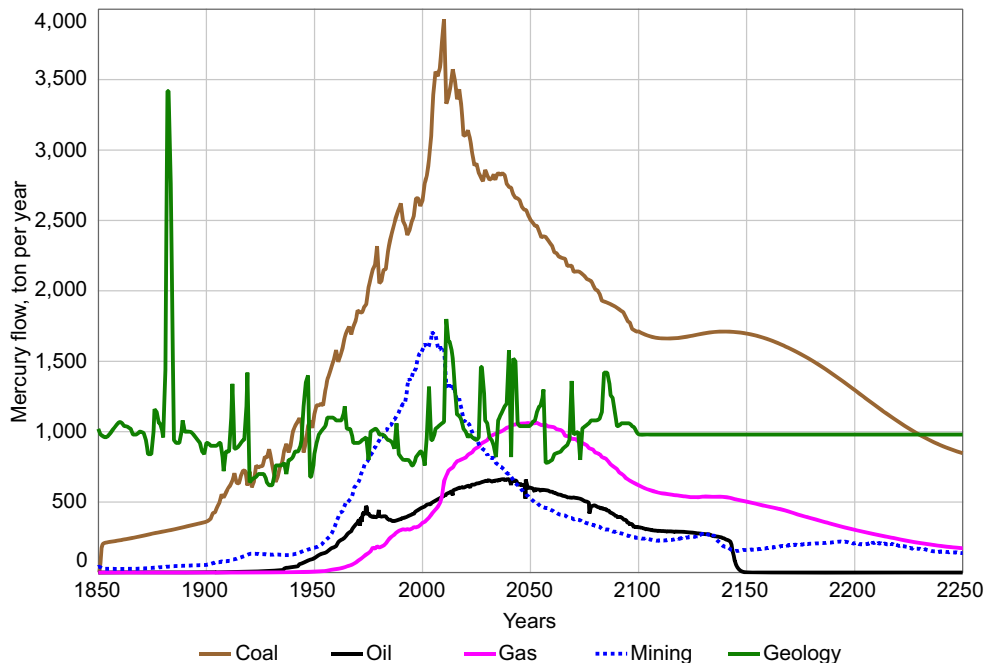




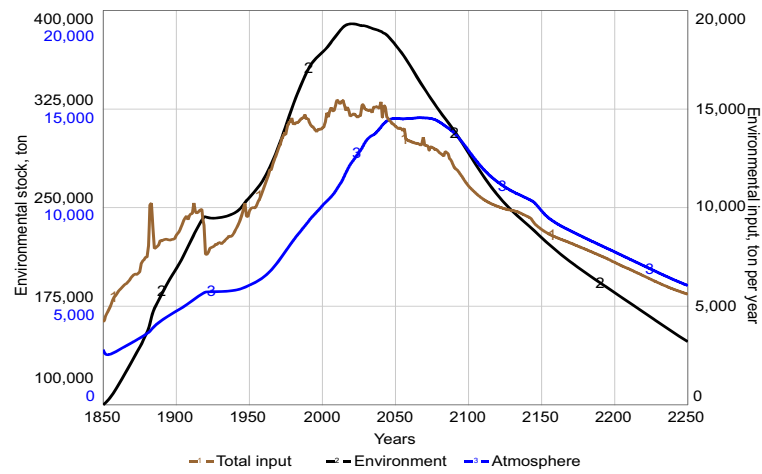

Fig. 10 (left) The simulated mercury impact in total, on the environment and the atmosphere. The graph shows the total input per year, the stock in the ecosystems and the stock in the

\section{Discussion}

Mercury is a very toxic element, and the available assessment literature allows for no illusions or denial of health effects from mercury exposure. The risk of mercury pollution and associated human health effect is a reason for phasing out coal as a power source. Because of the volatility of the polluting substance, mercury remains long in the ecosystems and has the potential to reach every living human on the planet. Thus, once pollution has been done, the next generations are stuck with it, and in terms of sustainability, it is an issue of intergenerational accountability. Climate change with increasing temperatures appears to have increased the re-volatilisation of mercury from old pollution, and environmental mercury pollution is still a problem.

Table 5 shows a very compelling reason why coal as a fuel should be phased out, based on mercury pollution alone. Releasing another 450,000 ton of mercury into nature would amount to a major environmental damage.

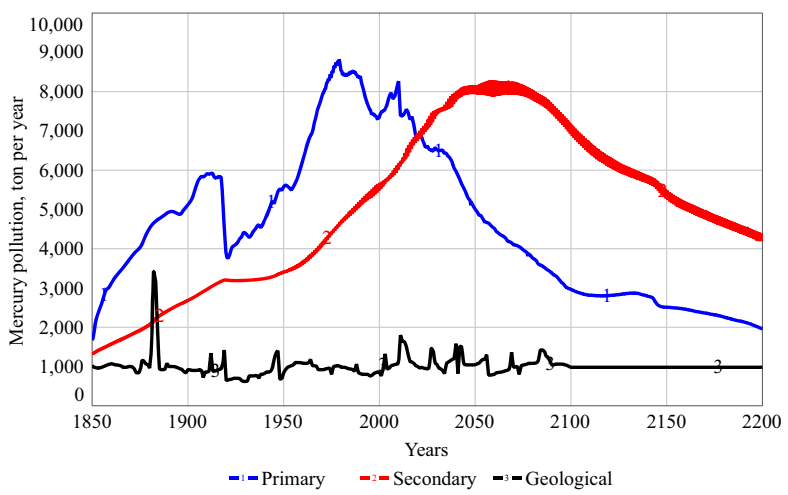

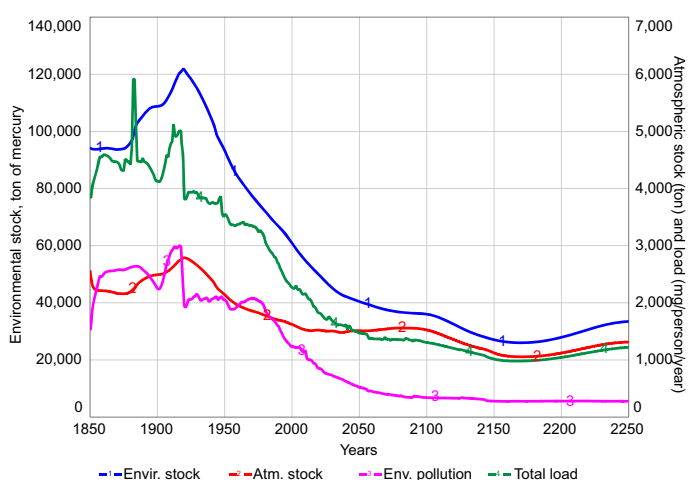

atmosphere. (right). The environmental stock per person, the atmospheric stock per person and the supply per person per year, and the total environmental input

It could have consequence for all types of vertebrate life, including humans (Bellanger et al. 2013). It would cause significant negative endocrine impacts, immune system impacts and central nerve system impacts in human, manifesting itself as public health issues (increased hospitalizations and infectious diseases) and cognitive capability decreases on a global level (loss of intelligence). It is also evident that continued coal combustion without smoke gas cleaning would release far too much mercury to the environment. Mercury pollution is particularly insidious damage as it is invisible, tasteless, odourless and technically difficult to measure at levels where it is still physiologically dangerous $\left(\mathrm{ng} / \mathrm{m}^{3}\right.$ or exposure in microgram per day).

There needs to be some reflections on the history of denial of science related to environmental issues and medical effects of mercury and the occurrence of lack of will to change, that was pervasive for a long time (Hylander et al. 2005; Danasekaran et al. 2013; Kegan and Laskow-Lahey 2014; Kotter 2014 for a discussion

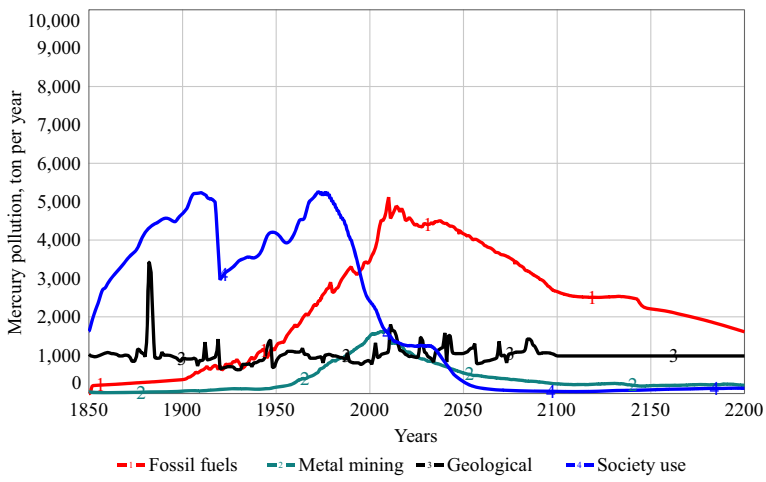

Fig. 11 (left) The primary, secondary and the geological mercury pollution. (right) The mercury pollution from fossil fuels combustion, pyrotechnical metal mining, geological pollution and from society use 
of how an issue can get stuck with some people that loses the ability to change). Those, in positions of power, need to seriously consider their environmental attitudes and policy with relation the next generation in many aspects, some of them also concerning global environmental aspects beyond the issue of mercury (Kegan and Laskow-Lahey 2014 Haraldsson et al, 2008). A need for contemplation to the dependence on future pension systems, the dependency of the future elderly care and health services, considering that those services will be provided, operated and paid for by the next generation. When sufficient numbers of the next generation (that are anticipated to provide that care, support and pensions), feel their future has been ruined, it may have ramifications for those that are perceived to have the blame for that ruined environment. It will be important to make sure the 2013 Minamata Convention is implemented properly and followed up in a way that it really works. This implying letting no mercury reach the market, and stop all production in all countries.

The future perspective of this work is that the effect of different changes in financial strategies, global economics, resource policy and energy politics can be assessed, even down to the level of global mercury pollution. Mercury pollution is a participant in the global pollution exposure with long-term effects on human public health. This can now be assessed.

\section{Conclusions}

It is concluded that the WORLD7 model presented represents the current history well enough to use it to make future policy predictions. The assessment of the mercury supply to society and the mercury environmental pollution are aspects of the same system as seen from different angles.

The main concern with mercury is for human health. A challenge is getting good human mercury exposure inputs to environmental assessments and human health assessments, set in the right context. Most of the mercury known will need to remain in the ground or to return there as long as we keep the knowledge of its great toxicity. Based on the outputs from the model, it is concluded that the mercury supply (and pollution) to society is in decline and will almost be phased out by the year 2050. The outputs confirm Zhang's conclusions that the atmospheric stock has started to decline as a result of declining industrial emissions (Zhang et al.
2015). The purpose of the present policy (2013 Minamata Convention) is to eliminate the supply to society and from the outputs it seems like that is working (European Parliament 2017).

The limitations on mercury future use by regulations, make sure that there will be no scarcity because of resource exhaustion.

Funding Information Open Access funding provided by Inland Norway University Of Applied Sciences.

Open Access This article is licensed under a Creative Commons Attribution 4.0 International License, which permits use, sharing, adaptation, distribution and reproduction in any medium or format, as long as you give appropriate credit to the original author(s) and the source, provide a link to the Creative Commons licence, and indicate if changes were made. The images or other third party material in this article are included in the article's Creative Commons licence, unless indicated otherwise in a credit line to the material. If material is not included in the article's Creative Commons licence and your intended use is not permitted by statutory regulation or exceeds the permitted use, you will need to obtain permission directly from the copyright holder. To view a copy of this licence, visit http://creativecommons.org/licenses/by/4.0/.

\section{References}

Albin, S. (1997). Building a system dynamics model; part 1; conceptualization. MIT system dynamics education project (J. Forrester (Ed)). MIT, Boston. 34pp. https://ocw.mit. edu/courses/sloan-school-of-management/15-988-systemdynamics-self-study-fall- 1998 -spring- 1999 /readings/building.pdf

AMAP/UNEP, (2013). (Arctic Monitoring and Assessment Programme/United Nations Environment Programme). Technical Background Report for the Global Mercury Assessment 2013. AMAP/UNEP Chemicals Branch, Geneva, Switzerland vi +263 pp.

AMAP/UNEP, (2015). Global mercury modelling: update of modelling results in the global mercury assessment 2013. Arctic Monitoring and Assessment Programme, Oslo, Norway/UNEP Chemicals Branch, Geneva, Switzerland. iv $+32 \mathrm{pp}$.

Amorim, M. I., Mergler, D., Bahia, M. O., Miranda, H., \& Lebel, J. (2000). Cytogenetic damage related to low levels of methylmercury contamination in the Brazilian Amazon. Ann Acad Bras Cienc, 72, 497-507.

Amos, H., Jacob, D., Streets, D., \& Sunderland, E. M. (2013). Legacy impacts of all-time anthropogenic emissions on the global mercury cycle. Global Biogeochemical Cycles, 27, 410-421.

Axelrad, D. A., Bellinger, D. C., Ryan, L. M., \& Woodruff, T. J. (2007). Dose-response relationship of prenatal mercury exposure and IQ: an integrative analysis of epidemiologic data. Environmental Health Perspectives, 115, 609-615. 
Bakir, T. F., Damluji, S. F., Amin-Zaki, L., Muttadha, M., Khalidi, M., Al-Rawi, N. Y., Tikriti, S., Dhahir, H. I., Clarckson, T. W., Smith, J. C., \& Doherty, R. H. (1973). Methylmercury poisoning in Iraq. Science, 181, 230-241.

Bakker, D., de Vries, W., \& Sverdrup, H. (1998). Effects-based approaches to assess the risk of heavy metal inputs to surface waters-overview methods and models. In: Workshop on critical limits and effect based approaches for heavy metals and persistent organic pollutants, Gregor, H., Spranger, T., Hörnerbach, F. (eds). Umweltbundesamt Texte, 5(98), 225278 issn 0722-186X.

Bellanger, M., Pichery, C., Aerts, D., Berglund, M., Castaño, A., Čjchanová, M., Crettaz, P., Davidson, F., Esteban, M., Fischer, M. E., Gurzau, A. E., Halzlova, K., Katsonouri, A., Knudsen, L. E., Kolossa-Gehring, M., Koppen, G., Ligocka, D., Višnjevec, A., Reis, M. F., Rudnai, P., Tratnik, J. S., Weihe, P., Budtz-Jørgensen, E., Grandjean, P., \& DEMO/COPHES. (2013). Economic benefits of methylmercury exposure control in Europe: monetary value of neurotoxicity prevention. Environmental Health, 12, 3.

Bellinger, D.C. (2005). Neurobehavioral assessments conducted in the New Zealand, Faroe Islands, and Seychelles Islands studies of methylmercury neurotoxicity in children. Report to the U.S. Environmental Protection Agency. EPA-HQ- OAR2002-0056-6045. Available: http://www.regulations.gov

Benford, D., Ceccatelli, S., Cottrill, B., di Novi, M., Dogliotti, E., Edler, L., Farmer, P., Fürst, P., Hoogenboom, L., Knutsen, H., Haldorsen, A.-K., Metzler, M., Nebbia, C., O'Keeffe, M., Rietjens, I., Schrenk, D., Silano, V., van Loveren, H., Vleminckx, C., \& Wester, P. (2012). Scientific opinion on the risk for public health related to the presence of mercury and methylmercury in food. EFSA panel on contaminants in the food chain (CONTAM). EFSA Journal, 10, 2985.

Bergan, T. Gallardo, L., Rodhe, H., 1999. Mercury in the global troposphere, a three-dimensional study. Atmospheric Environment 33-1575-1585.

Berlin. M, Mercury. Elsevier/North-Holland Biomedical Press, 1979.

Bernaudin, J. F., Druet, E., Druet, R., \& Masse, R. (1981). Inhalation or indigestion of organic and inorganic mercurials produces auto-immune disease in rats. Clinical Immunology and Immunopathology, 20, 129-135.

Bernhoft, R.A., 2012. Mercury toxicity and treatment: a review of the literature. J. Environ. Health: 10pages. doi: https://doi. org/10.1155/2012/460508.

Bingham, M. D. (1990). Field detection and implications of mercury in natural gas. SPE Production Engineering, 5, 120124. https://doi.org/10.2118/19357-PA.

Bossel, H. (1998). Earth at the crossroads. Paths to a sustainable future. Cambridge University Press.

Braid, B. (2007). Multiple sclerosis and heavy metals (a case history). Townsend Letter, 125-128.

Brooks, W.E., Sandoval, E., Yepez, M.A., Howell H., (2007). Peru mercury inventory 2006: U.S. Geological Survey Open-File Report 2007-1252, 55 pp., http://pubs.usgs. gov/of/2007/1252/.

Buchet, J. P., Roels, H., Bernard, A., \& Lauwerys, R. (1980). Assessment of renal function of workers exposed to inorganic lead, cadmium or mercury vapor. Journal of Occupational Medicine, 22, 741-750.
Camner, P., Clarckson, T., Nordberg, G.: 1979, Routes of exposure, dose and metabolism of metals, Elsevier/North-Holland Biomedical Press.

Cherian, M. G., Hursh, J. G., \& Clarkson, T. W. (1978). Radioactive mercury distribution in biological fluids and excretion in human subjects after inhalation of mercury vapour. Archives of Environmental Health, 33, 190-214.

Clarckson, T. (1979). Effects, general principles underlying the toxic action of metals. Elsevier/North-Holland Biomedical Press.

Clarkson, T. W., \& Magos, L. (2006). The toxicology of mercury and its chemical compounds. Critical Reviews in Toxicology, 36, 609-662.

Clewell, R.A. and Clewell III, H.J., 2008. Development and specification of physiologically based pharmacokinetic models for use in risk assessment Regulatory Toxicology and Pharmacology 50; 129-143.

Clifton, J. C. (2007). Mercury exposure and public health. Pediatric Clinics of North America, 54, 237-269.

Cooke, C.A., Balcom, P.H, Biester, H., Wolfe, A.P. (2009). Over three millennia of Mercury pollution in the Peruvian Andes, Proceedings of the National Academy of Science of the United States of America, 106, 8830-8834.

Cox, T. (1981). The effect of dental amalgams on mercury levels. Journal of Dental Research, 60, 1668-1671.

Danasekaran, R., Mani, M., \& Annadurai, A. (2013). Mercury free healthcare by 2020: time for action. Online Journal of Health and Allied Science, 12, 16.

Diaz, J. C. (2013). An assessment of primary and secondary mercury supplies in Mexico (119 pages). Quebec: Commission for Environmental Cooperation.

Doherty, M.J. (2003). The quicksilver prize: mercury vapor poisoning aboard HMS triumph and HMS Phipps. An account of the effect of mercurial vapours on the crew of his majesty's ship triumph, in the year 1810. By William Burnet, M.D. one of the medical commissioners of the navy, formerly physician and inspector of hospitals to the Mediterranean Fleet.

Driscoll, C., Mason, R., Chan, H., Jacob, D. J., \& Pirrone, N. (2013). Mercury as a global pollutant: sources, pathways, and effects. Environmental Science \& Technology, 47, 49674983.

Du, F., Warsinger, D. M., Urmi, T. I., Thiel, G. P., Amit Kumar, A., \& Lienhard, J. H. (2018). Sodium hydroxide production from seawater desalination brine: process design and energy efficiency. Environmental Science \& Technology. https://doi. org/10.1021/acs.est.8b01195.

E.C. (2017). Questions and answers: EU mercury policy and the ratification of the Minamata convention. European Commission fact sheet, available from: http://europa. eu/rapid/press-release_MEMO-17-1344_en.htm,

Ehrlich, P. (1910a). Die Behandlung der Syphilis mit dem Ehrlichschen Präparat 606. Deutsche medizinische Wochenschrift: 1893-1896.

Ehrlich, P. (1910b). Anwendung und Wirkung von Salvarsan. Deutsche Medizinische Wochenschrift, 2437-2438.

Ekino, S., Susa, M., Ninomiya, T., Imamura, K., \& Kitamura, T. (2007). Minamata disease revisited: an update on the acute and chronic manifestations of methyl mercury poisoning. Journal of the Neurological Sciences, 262, 131-144. https://doi.org/10.1016/j.jns.2007.06.036. 
Eneström. S. (1989). Kvicksilver påverkar immunförsvaret. In: I. Atterstam, (Ed.) Striden om amalgamet, Forskarnas debatt om kvicksilveret i tandvården. Källa 33:77-80. Forskningsrådsnämden.

EU Commission. (2018). Science for environment policy. Indepth report 15:Tackling mercury pollution in the EU and worldwide. $72 \mathrm{pp}$. ISBN: 978-92-79-43999-5 http://ec. europa.eu/environment/chemicals/Mercury/pdf/tackling_ Mercury_pollution_EU_and_worldwide_IR15_en.pdf

European Environmental Agency (2018). Mercury pollution remains a problem in Europe and globally. https://www.eea. europa.eu/highlights/mercury-pollution-remains-a-problem

European Parliament (2017). Briefing for Minamata convention COP1. Policy Department A: Economy and Scientific and Quality of Life Policies, 24 Economy and Scientific and Quality of Life Policies, European Parliament PE 607.347. Key issues at stake at COP1 on the Minamata Convention. Geneva, pages 24-29, September 2017. http://www.europarl. europa.eu/RegData/etudes/BRIE/2017/607347/IPOL BRI(2017)607347_EN.pdf.

Forrester, J.W. (1961). Industrial dynamics. Pegasus Communications. ISBN 1-883823-36-6.

Forrester, J.W. (1969). Urban dynamics. Pegasus Communications. ISBN 1-883823-39-0.

Forrester, J. W. (1971). World dynamics. Waltham MA: Pegasus Communications.

Friberg, L. (1951). Chronic poisoning with inorganic mercury compounds. Nordisk Hygienisk Tidskrift, 32, 240-249.

Friberg, L., \& Chairman. (1969). Report of an international committee. Maximum allowable concentrations of mercury compounds. Archives of Environmental Health, 19, 891-905.

G A M A $2009 \quad$ h t t p s : / / c 1 u - i n . org/download/contaminantfocus/mercury/Mercury-CAfs.pdf

GBD (2016). Risk factors collaborators 2017. Global, regional, and national comparative risk assessment of 84 behavioural, environmental and occupational, and metabolic risks or clusters of risks, 1990-2016: a systematic analysis for the Global Burden of Disease Study 2016, Global Health Metrics 390: 1345-1422. https://www.thelancet.com/action/showPdf?pii=S0140-6736 $\% 2817 \% 2932366-8$

Gerson, A. R., Cristol, D. A., \& Seewagen, C. L. (2019). Environmentally relevant methylmercury exposure reduces the metabolic scope of a model songbird. Environmental Pollution, 246, 790-796. https://doi.org/10.1016/j. envpol.2018.12.072.

Gore, A. C., Chappell, V. A., Fenton, S. E., Flaws, J. A., Nadal, A., Prins, G. S., Toppari, J., \& Zoeller, R. T. (2015). Executive Summary to EDC-2: the endocrine society's second scientific statement on endocrine-disrupting chemicals. Endocrine Reviews, 36, 593-602.

Gregor, H.-D., Mohaupt-Jahr, B., Hönerbach, F. (1999). Workshop on effects-based approaches for heavy metals, Schwerin, Germany, 12-15 October 1999, Proceedings, UBA Texte 87/99, Umweltbundesamt, Berlin.

Hanson, M. (1986). Förändringar i hälsotillståndet efter utbyte av giftiga tandfyllningmaterial. En epidemiologisk studie av 519 personer med misstänkt kvicksilverförgiftning från amalgam, Tf-bladet nr 1, 1986;

Hanson, M. (1989a). Why is mercury toxic? Basic chemical and biochemical properties of mercury/amalgam in relation to biological effects. In: Proceedings of the International
Conference on biocompatibility of materials. Life Science Press.

Hanson, M. (1989b). Changes in health caused by exchange of toxic metallic dental restorations, Bio-Probe Newsletter 5.

Hanson, M. (1989c). Fosterskadande effekter av kvicksilver. Jordemodern, 98.

Hanson, M. (1998). Amalgam - huvudkällan till människors kvicksilverexponering, in: Kvicksilver, amalgam och oral galvanism: FRNs rapport till regeringen, Dnr 970798:7.

Haraldsson, H. (2004). Introduction to systems thinking and causal loop diagrams. Reports in ecology and environmental engineering 1:2004, 5th edition. Lund University, Lund, Sweden.

Haraldsson, H. and Sverdrup, H. (2005). On aspects of systems analysis and dynamics workflow. Proceedings of the systems dynamics society, July 17-21, 2005 International conference on systems dynamics, Boston, USA. 10 pages. http://www. s y s t e m d y n a m i c s.org/con ferences/2005 /proceed/papers/HARAL310.pdf

Haraldsson, H., Sverdrup, H., Belyazid, S., Holmqvist, J., \& Gramstad, R. C. J. (2008). The tyranny of small steps: a reoccurring behaviour in management. Systems Research and Behavioral Science, 25, 25-43.

Haraldsson, H.V., Belyazid, S., Sverdrup, H. (2006). Causal Loop Diagrams, promoting deep learning of complex systems in engineering education. In: Alveteg, M. and Leire, E. (Eds.) LTH pedagogiske inspirasjonskonferens , 1-4.

Hirschnitz-Garbers, M., Distelkamp, M., Koca, D., Meyer, M., Sverdrup, H.U., (2017). Potentiale und Kernergebnisse der Simulationen von Ressourcenschonung(spolitik) Endbericht des Projekts „Modelle, Potentiale und Langfristszenarien für Ressourceneffizienz" (SimRess). Editierendes Institut: Ecologic Institut, Pfalzburger Str. 43-44, DE-10717 Berlin. Forschungskennzahl 3712-93-102, UBA-FB-00. Umweltforschungsplan des Bundesministeriums für Umwelt, Naturschutz, Bau und Reaktorsicherheit.

Hirschnitz-Garbers, M., Koca, D., Sverdrup, H., Meyer, M., Distelkamp, M. (2018). System analysis for environmental policy - system thinking through system dynamic modelling and policy mixing as used in the SimRess project models, potential and long-term scenarios for resource efficiency (SimRess) Texte 50-2018. 281 pages. FKZ 371293 102, Verlag Umweltbundesamt. Berlin. https://www. umweltbundesamt.de/publikationen/system-analysis-forenvironmental-policy-system-0

Hirschnitz-Garbers, M., Langsdorf, S., Sverdrup, H.; Koca, D.; Distelkamp, M., Meyer, M. (2015). Integrated modelling for resource policy assessment - the SimRess-project. Proceedings of the 2015 Word resources forum, 11-15 September. Davos, Switzerland..

Hong, Y. S., Kim, Y. M., \& Lee, K. E. (2012). Methylmercury exposure and health effects. Yebang Uihakhoe Chi., 45, 353363. https://doi.org/10.3961/jpmph.2012.45.6.353.

Hu, X. F., Singh, K., \& Chan, C. M. (2018). Mercury exposure, blood pressure, and hypertension: a systematic review and dose-response meta-analysis. Environmental Health Perspectives, 7, 1-15. https://doi.org/10.1289/EHP2863.

Hunter, D., Bomford, R. R., \& Russell, D. S. (1940). Poisoning by methylmercury compounds. Quarterly Journal of Medicine, 9, 193-213.

Hylander, L., Carlsson, E., Dalén, P., Regnell, O., Sverdrup, H. (2005). Starta dialog om kvicksilvret. Ny Teknik nr. 36, 7 
sep. sid. 30 http://urn.kb.se/resolve?urn=urn:nbn:se:uu:diva77133

Ibrahim, D., Froberg, B., Wolf, A., \& Rusyniak, D. E. (2006). Heavy metal poisoning: clinical presentations and pathophysiology. Clinics in Laboratory Medicine, 26, 67-97.

Jainshankar, M., Tseten, T., Anbalagan, N., Mathew, B.B., Beeregowda, K., 2014, Toxicity, mechanism and health effects of some heavy metals Interdiscip Toxicol. 2014; Vol. 7(2): 60-72. https://doi.org/10.2478/intox-2014-0009.

Jensen, G. and Ruzickova, K. (2006). Halting the child brain drain. Why we need to tackle global mercury contamination. Chapter 1: How does mercury affect your health. Pages 820. https://www.env-health.org/IMG/pdf/2-_Halting the child brain drain Why we need to tackle global Mercury_contamination.pdfhttps://www.env-health. org/IMG/pdf/Mercury_chapter1.pdf

Kegan, R., Laskow-Lahey, L. (2014). The real reason people won't change. Harvard Business Review - OnPoint 103111. Originally published in Harvard Business review November 2001.

Kerfoot, C., Harting, S. L., Jeong, J., Robbins, J. A., \& Rossmann, R. (2004). Local, regional, and global implications of elemental mercury in metal (copper, silver, gold, and zinc) ores: insights from Lake Superior sediment. Journal of Great Lakes Research, 30, 162-184.

Kerfoot, W.C., Harting, S.L., Rossmann, R., Robbins, J.A., 2000. Mercury in metal ore deposits: an unrecognized, widespread source to Lake Superior sediments. In: Nriagu, J (ed) 11th Annual International Conference on Heavy Metals in the Environment, Contribution. University of Michigan, School of Public Health, Ann Arbor, CD-ROM.

Kim, D. H. (1992). Toolbox: guidelines for drawing causal loop diagrams. The Systems Thinker, 3, 5-6.

Koca, D., Sverdrup, H., Ragnararsdottir, K.V., (2017). Kausalschleifendiagramme als narrative VisualisierungsTools für Kommunikation und Analyse komplexer dynamischer Systeme: Konzeptuelle Modellierung und Systemanalyse von komplexen Mensch-/NaturSysteminteraktionen in einer Welt mit begrenzten Ressourcen als Beispiel. In: Biemann, K, Distelkamop, M., Dittrich, M., Dünnbell, Greiner, B., Hirschnitz-Garber, M., Koca, D., Sverdrup, H., Kosow, H., Lorenz, U., Mellwig, P., Meyer, M., Neumann, K., Schoer, K., van Oechsen, A., WeimerJehle, W., (Eds). Sicherung der Konsistenz und Harmonisierung von Annahmen bei der kombinierten Modellierung von Ressourceninanspruchnahme und Treibhausgasemissionen. Reader zum Erfahrungsaustausch im Rahmen des SimRess-Modellierer-Workshops am 7-8 Dezember in Berlin. Simulation Ressourceninanspruchnahme und Ressourceneffizienzpolitik Pages 37-45. DOKUMENTATIONEN 04/2017 Umweltforschungsplan des Bundesministeriums für Umwelt, Naturschutz, Bau und Reaktorsicherheit Forschungskennzahl 371293102 ISSN 2199-6571 Dessau-Roßlau, Januar 2017.

Kotter, J.P. (2014). Leading change; why transformations efforts fail. Harvard Business Review - OnPoint 30-37. Originally published in Harvard Business review April 1995.

Krabbenhoft, D. and Schuster, P. (2002). Glacial ice cores reveal a record of natural and anthropogenic atmospheric mercury deposition for the last 270 years. USGS Fact Sheet.
Available from: https://toxics.usgs.gov/pubs/FS-051-02 $/ \mathrm{pdf} / \mathrm{fs}-051-02 . \mathrm{pdf}$

Krabbenhoft, D., \& Sunderland, E. M. (2013). Global change and mercury. Science, 341, 1457-1458.

Lamborg, C. H., Fitzgerald, W. F., O'Donnel, J., \& Torgersen, T. (2002). A non-steady-state compartmental model of globalscale mercury biogeochemistry with interhemispheric atmospheric gradients. Geochimica et Cosmochimica Acta, 66, $1105-1118$.

Langford, N. J., \& Ferner, R. E. (1999). Toxicity of mercury. Journal of Human Hypertension, 13, 651-666.

Lauwerys, R. R., \& Buchet, J. P. (1973). Occupational exposure to mercury vapors and biological action. Archives of Environmental Health, 27, 65-68.

Lee, S., Tan, Y.M., Phillips, M.B., Sobus, J.R., Kim, S., 2017. Estimating methylmercury intake for the general population of South Korea using physiologically based pharmacokinetic modeling. Toxicol Sci. 159: 6-15.

Lelieveld, J., Evans, J. S., Fnais, M., Giannadaki, D., \& Pozzer, A. (2015). The contribution of outdoor air pollution sources to premature mortality on a global scale. Nature, 525, 367-371.

Levy, M. (1995a). Dental amalgam: toxicological evaluation and health risk assessment I. Journal of the Canadian Dental Association, 61, 667-668.

Levy, M. (1995b). Dental amalgam: toxicological evaluation and health risk assessment II. Journal of the Canadian Dental Association, 61, 671-674.

Lindberg, S. E., Hanson, P. J., Meyers, T. P., \& Kim, K.-H. (1998). Air/surface exchange of mercury vapor over forests: The need for a reassessment of continental biogenic emissions. Atmospheric Environment, 32, 895-908.

Lindberg, S. E., Meyers, T. P., Taylor Jr., G. E., Turner, R. R., \& Schroeder, W. H. (1992). Atmospheric surface exchange of mercury in a forest; results of modeling and gradient approaches. Journal of Geophysical Research, 97, 2519-2528.

Lindh, U. (1989). Kvicksilver spåras i blodet. In: I. Atterstam, (ed), Striden om amalgamet-Forskarnas debatt om kvicksilveret $\mathrm{i}$ tandvården Källa 33:72-76. Forskningsrådsnämnden..

Lorenz, U., Sverdrup, H.U., Ragnarsdottir, K.V. (2017). Global megatrends and resource use - A systemic reflection. Chapter 3. In Lehman, H. (Ed) The Factor X book (pp. 6777). Frankfurt: Springer Verlag.

Mann, S., Droz, P.O., Vahter, M., 1996a. A physiologically based pharmacokinetic model for arsenic exposure. I. Development in hamsters and rabbits. Toxicol. Appl. Pharmacol. 137, 8 22.

Mann, S., Droz, P.O., Vahter, M., 1996b. A physiologically based pharmacokinetic model for arsenic exposure. II. Validation and application in humans. Toxicol. Appl. Pharmacol. 140, 471-486.

Mayer, R. (1975). Arbetshygienische untersuchungen bei der verarbeitung von silber-zinn-quecksilberlegierungen in der mundhöhle. Deutche zahnärztliche Zeitschrift, 30, 246-253.

Meadows, D. L., Behrens III, W. W., Meadows, D. H., Naill, R. F., Randers, J., \& Zahn, E. K. O. (1974). Dynamics of growth in a finite world. Massachusetts: Wright-Allen Press, Inc..

Meadows, D.H., Meadows, D.L., Randers, J. (1992). Beyond the limits: confronting global collapse, envisioning a sustainable future. Chelsea Green Publishing Company:

Meadows, D. H., Meadows, D. L., Randers, J., \& Behrens, W. (1972). Limits to growth. New York: Universe Books. 
Meadows, D.H., Randers, J., Meadows, D. (2005). Limits to growth. The 30 year update. Universe Press, New York.

Meili, M., Bishop, K., Bringmark, L., Johansson, K., Hultberg, H., Munthe, J., Sverdrup, H., de Vries, W. (2001). The maximum tolerable atmospheric pollution. Criteria, concepts and application of a minimized model. In: Report from the Ad Hoc Expert Meeting in Bratislava, Slovakia 66-67, J. Curlik, (Ed.). Peer reviewed through a series of official UN/ECE workshops held in Schwerin, Berlin and Bratislava. Published by the Slovak Ministry of Environment, Bratislava, 2001.

Meili, M., Bishop, K., Bringmark, L., Johansson, K., Munthe, J., Sverdrup, H., \& de Vries, W. (2003). Critical levels of atmospheric pollution: criteria and concepts for operational modelling of mercury in forests and lake ecosystems. Science of the Total Environment, 304, 83-106.

Meinert, L. D., Robinson, G. R., \& Nassar, N. T. (2016). Mineral resources; reserves, peak production and the future. Resources, 5, 14. https://doi.org/10.3390/resources5010014.

Mojammal, A. H. M., Back, S. K., Seo, Y. C., \& Kim, J. H. (2019). Mass balance and behavior of mercury in oil refinery facilities. Atmospheric Pollution Research, 10, 145-151.

Ngim, C. H., Foo, S. C., Boey, K. W., \& Keyaratnam, J. (1992). Chronic neurobehavioral effects of elemental mercury in dentists. British Journal of Industrial Medicine, 49, 782-790.

Ninomiya, T., Ohmori, H., Hashimoto, K., Tsuruta, K., \& Ekino, S. (1995). Expansion of methylmercury poisoning outside Minamata: an epidemiological study on chronic methylmercury poisoninig outside of Minamata. Environmental Research, 70, 47-50.

Nriagu, J. O. (1994). Mercury pollution from the past mining of gold and silver in the Americas. Science of the Total Environment, 149, 167-181.

Nriagu, J., \& Becker, C. (2003). Volcanic emissions of mercury to the atmosphere: global and regional inventories. Science of the Total Environment, 20, 3-12.

Olafsdottir, A. H. and Sverdrup, H. (2019). Defining a conceptual model for market mechanisms in food supply chains, and parameterizing price functions for coffee, wheat, corn, soy beans, beef and salmon. International Journal of Food System Dynamics, 10: 151-175.https://doi.org/10.18461 /ijfsd.v10i2.14.

Pacyna, E. G., Pacyna, J. M., Steenhuisen, F., \& Wilson, S. (2006). Global anthropogenic mercury emission inventory for 2000. Atmospheric Environment, 40, 4048-4063.

Pacyna, E.G., Pacyna, J.M., Sundseth, K., Munthe, J., Kindbom, K., Wilson, S., Steenhuisen, F., Maxson, P. 2010. Global emission of mercury to the atmosphere from anthropogenic sources in 2005 and projections to 2020 Atmospheric Environment 44, 2487-2499.

Pelletier, L., Pasquier, R., Hirsch, F., Sapin, C., \& Druet, P. (1986). Autoreactive T-cells in mercury induced autoimmune disease: in vitro demonstration. Journal of Immunology, 137, 2548-2554.

Perry, H. M., \& Erlanger, M. W. (1974). Metal-induced hypertension following chronic feeding of low doses of cadmium and mercury. Journal of Laboratory and Clinical Medicine, 83, 541-547.

Pinheiro, M. C. N., Macchi, B. M., Vieira, J. L. F., Oikawa, T., Amoras, W. W., \& Santos, E. O. (2008). Mercury exposure and antioxidant defenses in women: a comparative study in the Amazon. Environmental Research, 107, 53-59 [PubMed: 17905226].

Pirrone, N., Cinnirella, S., Feng, X., Finkelmann, R. B., Friedeli, H. R., Leaner, J., Mason, R., Mukherjee, A. B., Stracher, G. B., Streets, D. G., \& Telmer, K. (2010). Global mercury emissions to the atmosphere from anthropogenic and natural sources. Atmospheric Chemical Physics, 10, 5951-5964.

Popescu, H. I., Negru, L., \& Lancranjan, I. (1979). Chromosome aberrations induced by occupational exposure to mercury. Archives of Environmental Health, 34, 461-463.

Rehman, K., Fatima, F., Waheed, I., \& Akash, M. S. H. (2018). Prevalence of exposure of heavy metals and their impact on health consequences. Journal of Cellular Biochemistry, 119, 157-184.

Roberts, N., Andersen, D.F., Deal, R.M., Shaffer, W.A. 1982, Introduction to computer simulation: a system dynamics approach productivity press, Chicago.

Rooney, J. P. K. (2014). The retention time of inorganic mercury in the brain - a systematic review of the evidence. Toxicology and Applied Pharmacology, 274, 425-435.

Rytuba, J.J. (2002). Mercury geoenvironmental models. In: Seal R.R., Foley N. (eds) Geoenvironmental analysis of ore deposits, US Geological Survey Open File Report 02-195:161175, http://pubs.usgs.gov/of/2002/of02-195/.

Rytuba, J. J. (2003). Mercury from mineral deposits and potential environmental impact. Environmental Geology, 43, 326338. https://doi.org/10.1007/s00254-002-0629-5.

Sangster, D. F. (1990). Mississippi valley-type and sedex leadzinc deposits: a comparative examination. Transactions of the Institution of Mining and Metallurgy, 99, B21-B42.

Schloss, L. (2019). Legislation, standards and methods for mercury emissions control. IEA Clean Coal Centre, CCC/195. ISBN 978-92-9029-515-0. https://doi.org/10.13140 /RG.2.2.30155.34087.

Schwartz, M. O. (1997). Mercury in zinc deposits: economic geology of a polluting element. International Geological Review, 39, 905-923.

Schwartz, M.O., 2008. Modelling groundwater contamination above the Asse 2 medium-level nuclear waste repository, Germany. Environ Earth Sci. 11 pages. DOI https://doi. org/10.1007/s12665-009-0025-5.

Schwenk, M., Klein, R., \& Templeton, D. M. (2009). Immunological effects of mercury. Pure and Applied Chemistry, 81, 153-167.

Scoullos, M.J.. Mercury — Cadmium — Lead handbook for sustainable heavy metals policy and regulation (Environment \& Policy). Springer Netherlands. 2001. ISBN: 978-94-010-0403-9.

Seifert, P., \& Neudert, H. (1954). The question of occupational mercury poisoning. Zentralbl. Arbeitsmed. Arbeitsschutz, 4, 129-137.

Selin, N. E. (2009). Global biogeochemical cycling of mercury: a review. Annual Review of Environment and Resources, 34, 43-63.

Senge, P. (1990). The fifth discipline. the art and practice of the learning organisation. New York: Century Business.

Senge, P. M., Smith, B., Schley, S., Laur, J., \& Kruschwitz, N. (2008). The necessary revolution: how individuals and organisations are working together to create a sustainable world. London: Doubleday Currency. 
Smith-Downey, N. V., Sunderland, E. M., \& Jacob, D. J. (2010). Anthropogenic impacts on global storage and emissions of mercury from terrestrial soils: insights from a new global model. Journal of Geophysical Research, 115, G03008. https://doi.org/10.1029/2009JG001124.

State Council of the People's Republic of China (SC). (2013). Action plan of national air pollution prevention and control, $S C$. China: Beijing.

Sterman J. D. (2000). Business dynamics, system thinking and modeling for a complex world. New York: Irwin McGrawHill.

Stock, A. (1926). Die gefährlichkeit des Quecksilberdampfes. Zeitschrift für Angewandte Chemie, 39, 461-488.

Stock, A. (1934a). Aufnahme und verteilung des Quecksilbers im Organismus. Zeitschrift für Angewandte Chemie, 49(801812), 1934.

Stock, A. (1934b). Über verdampfung, löslichkeit und oxidation des metallischen Quecksilbers. Zeitschrift für Anorganische und Allgemeine Chemie, 217, 241-253.

Stock, A. (1935). Die wirkungen von Quecksilberdampf auf die oberen Luftwege. Naturwissenschaften, 23, 453-456.

Streets, D. G., Hao, J. M., Wu, Y., Jiang, J. K., Chan, M., Tian, H. Z., \& Feng, X. B. (2005). Anthropogenic mercury emissions in China. Atmospheric Environment, 39, 7789-7806.

Streets, D. G., Horowitz, H. M., Jacob, D. J., Lu, Z., Levin, L., ter Schure, A. F. H., \& Sunderland, E. M. (2017). Total mercury released to the environment by human activities. Environmental Science \& Technology, 51, 5969-5977.

Streets, D. G., et al. (2011). All-time releases of mercury to the atmosphere from human activities. Environmental Science \& Technology, 45, 10485-10491.

Sundseth, K., Pacyna, J., Pacyna, E., Pirrone, N., \& Thorne, R. (2017). Global sources and pathways of mercury in the context of human health. International Journal of Environmental Research and Public Health, 14, 105.

Svare, C. W., Peterson, L. C., Reinhardt, J. W., Boyer, D. B., Frank, C. W., Gay, D. D., \& Cox, R.-D. (1981). The effect of dental amalgams on mercury levels. Journal of Dental Research, 60, 1668-1671.

Sverdrup, H. (2001). Setting critical limits for mercury, cadmium and lead to be used in calculation of critical loads for different receptors. In: Report from the Ad Hoc Expert Meeting in Bratislava, Slovakia, 93-100, J. Curlik, P. Sefcik, Z. Viechova (Eds.). Peer reviewed through a series of official UN/ECE workshops held in Schwerin, Berlin and Bratislava. Published by the Slovak Ministry of Environment, Bratislava, 2001.

Sverdrup, H. (Ed.), Haraldsson, H., Olafsdottir, A.H., Belyazid, S. 2018 System thinking, system analysis and system dynamics: find out how the world works and then simulate what would happen. 3rd revised edition. Háskolaprent Reykjavik. 310pp. ISBN 978-9935-24-425-3.

Sverdrup, H. (2017). Modelling global extraction, supply, price and depletion of the extractable geological resources with the LITHIUM model. Resources, Conservation and Recycling, 114: 112-129.

Sverdrup, H.U. (2019). The global sustainability challenges in the future: the energy and materials supply, pollution, climate change and inequality nexus. In: Holden, E., Meadowcraft, J. Langhelle, O., Banister, D., Linnerud, K., (Eds), Our common future, what next for sustainable development?. 30 years after the Brundtland report. Chapter 1: 7-27, springer Verlag, Frankfurt. Accepted.

Sverdrup, H. and Ashmore, M., (2001). Conclusion from the Ad Hoc Expert meeting on setting critical limits for heavy metals. 11-13 October 2000 in Bratislava, Slovakia, under the auspices of the UN-ECE and the ICP on modelling and mapping. In: Report from the Ad Hoc Expert Meeting in Bratislava, Slovakia, 109-125, J. Curlik, P. Sefcik, Z. Viechova (Eds.). Peer reviewed through a series of official UN/ECE workshops held in Schwerin, Berlin and Bratislava. Published by the Slovak Ministry of Environment, Bratislava.

Sverdrup, H.U., and Koca, D. (2017). Der Einsatz des WORLDModells im SimRess-Projekt: Sys- temgrenzen, ModellInteraktion, Indikatoren und grundsätzliche Ergebnisse. In: Biemann, K, Distelkamop, M., Dittrich, M., Dünnbell, Greiner, B., Hirschnitz-Garber, M., Koca, D., Sverdrup, H., Kosow, H., Lorenz, U., Mellwig, P., Meyer, M., Neumann, K., Schoer, K., van Oechsen, A., Weimer-Jehle, W., (Eds). Sicherung der Konsistenz und Harmonisierung von Annahmen bei der kombinierten Modellierung von Ressourceninanspruchnahme und Treibhausgasemissionen. Reader zum Erfahrungsaustausch im Rahmen des SimRessModellierer-Workshops am 7-8 Dezember in Berlin Simulation Ressourceninanspruchnahme und Ressourceneffizienzpolitik. Pages 49-71 DOKUMENTATIONEN 04/2017 Umweltforschungsplan des Bundesministeriums für Umwelt, Naturschutz, Bau und Reaktorsicherheit Forschungskennzahl 371293102 ISSN 2199-6571 Dessau-Roßlau, Januar 2017. Open access.

Sverdrup, H. and Koca, D. (2018). The WORLD model development and the integrated assessment of the global natural resources supply. 445 pages. Texte 100-2018. FKZ 3712 93 102, Verlag Umweltbundesamt. Berlin. https://www. umweltbundesamt.de/publikationen/the-world-modeldevelopment-the-integrated

Sverdrup, H.U., Koca, D., Ragnarsdottir, K.V. (2014). Investigating the sustainability of the global silver supply, reserves, stocks in society and market price using different approaches. Resources, Conservation and Recycling 83:121140 , open access:https://doi.org/10.1016/j. resconrec.2013.12.008

Sverdrup, H., Koca, D., \& Ragnarsdottir, K. V. (2015). Aluminium for the future: modelling the global production, assessing long term supply to society and extraction of the global bauxite reserves. Resources, Conservation and Recycling, 103, 139-154.

Sverdrup, H., \& Olafsdottir, A. H. (2018). A system dynamics model assessment of the supply of niobium and tantalum using the WORLD6 model. Biophysical Economics and Resource Quality, 4, 1-42.

Sverdrup, H., and Olafsdottir, A.H., (2019a). Conceptualization and parameterization of the market price mechanism in the WORLD6 model for metals, materials and fossil fuels. Mineral Economics 1-26. Springer Nature DOI: https://doi. org/10.1007/s13563-019-00182-7.

Sverdrup, H., and Olafsdottir, A.H. (2019b). Assessing the longterm global sustainability of the production and supply for stainless steel. Biophysical Economics and Resource Quality 1-26. https://doi.org/10.1007/s41247-019-0056-9 open access publication. 
Sverdrup, H, Olafsdottir, A.H., Ragnarsdottir, K.V. (2019). Assessing global copper, zinc and lead extraction rates, supply, price and resources using the WORLD6 integrated assessment model. Resources, Conservation and Recycling 126. X4 100007. https://doi.org/10.1016/j.rcrx.2019.100007. Open access publication.

Sverdrup, H., Olofsdottir, A. H., Ragnarsdottir, K. V., \& Koca, D. (2018). A system dynamics assessment of the supply of molybdenum and rhenium used for superalloys and specialty steels, using the WORLD6 model. Biophysical Economics and Resource Quality, 4, 1-52. https://doi.org/10.1007 /s41247-018-0040-9.

Sverdrup, H. and Ragnarsdottir, K.V., (2014). Natural resources in a planetary perspective. Geochemical Perspectives Vol. 3, number 2, October issue 2014. 2:129-341. European Geochemical Society. Open access.

Sverdrup, H., \& Ragnarsdottir, K. V. (2016). The future of platinum group metal supply; an integrated dynamic modelling for platinum group metal supply, reserves, stocks-in-use, market price and sustainability. Resources, Conservation and Recycling, 114, 130-152.

Sverdrup, H., Ragnarsdottir, K.V., (2017). Modelling the global primary extraction, supply, price and depletion of the extractable geological resources using the COBALT model. Biophysical Economics and Resource Quality. Vol 2:1, section 4: 29 pages. https://doi.org/10.1007/s41247-017-0017-0

Sverdrup, H., Ragnarsdottir, K. V., \& Koca, D. (2014). On modelling the global copper mining rates, market supply, copper price and the end of copper reserves. Resources, Conservation and Recycling, 87, 158-174. https://doi. org/10.1016/j.resconrec.2014.03.007.

Sverdrup, H., Koca, D., Ragnarsdottir K.V. (2017a). Defining a free market: Drivers of unsustainability as illustrated with an example of shrimp farming in the mangrove forest in South East Asia. Journal of Cleaner Production, 140: 299-311, https://doi.org/10.1016/j.jclepro.2015.06.087.

Sverdrup, H. U., Ragnarsdottir, K. V., \& Koca, D. (2017b). An assessment of global metal supply sustainability: global recoverable reserves, mining rates, stocks-in-use, recycling rates, reserve sizes and time to production peak leading to subsequent metal scarcity. Journal of Cleaner Production, 140, 359-372. https://doi.org/10.1016/j.jclepro.2015.06.085.

Sverdrup, H., Warfvinge, P., Hultberg, H., Andersson, B.I., Moldan F. 1998 Modelling soil acidification and recovery in a roofed catchment; Application of the SAFE model. In: H. Hultberg and R. Skeffington (Eds.) Experimental Reversal of Acid Rain Effects; The Gärdsjön Roof Project: 363-382. John Wiley Science.

Sverdrup, H., Warfvinge, P., Sverdrup, C. (1990). A model for mercury exposure due to metallic mercury spills. In: D. Walkinshaw, (Ed.), Indoor Air '90, 5:225-230. Canada Mortgage and Housing Corporation, 1990.

Swearengin M (2008). Man dies from mercury poisoning after trying to extract gold. Durant Daily Democrat.

Tchounwou, P. B., Yedjou, C. G., Patlolla, A. K., \& Sutton, D. J. (2012). Heavy metals toxicity and the environment. EXS, 101, 133-164. https://doi.org/10.1007/978-3-7643-83404 6.

Telmer, K. and Veiga, M. (2009). World emissions of mercury from artisanal and small scale gold mining, in Pirrone, N. and Mason, R.; mercury fate and transport in the global atmosphere: emissions measurements and models. Springer: New York. ISBN: 978-0-387-93958-2.

Tian, H. Z., Wang, Y., Xue, Z. G., Cheng, K., Qu, Y. P., Chai, F. H., \& Hao, J. M. (2010). Trend and characteristics of atmospheric emissions of $\mathrm{Hg}$, As, and Se from coal combustion in China, 1980-2007. Atmospheric Chemistry and Physics, 10, 11905-11919.

Tian, H. Z., Zhu, C. Y., Gao, J. J., Cheng, K., Hao, J. M., Wang, K., Hua, S. B., Wang, Y., \& Zhou, J. R. (2015). Quantitative assessment of atmospheric emissions of toxic heavy metals from anthropogenic sources in China: historical trend, spatial distribution, uncertainties, and control policies. Atmospheric Chemistry and Physics, 15, 10127-10147.

Toxicological Profile for Mercury. U.S. Department of Health and Human Services. March, 1999. http://www.atsdr.cdc. gov/toxprofiles/tp.asp?id=115\&tid=24.

U.S. FDA and U.S. EPA (2004). What you need to know about mercury in fish and shellfish, Advice for women who might become pregnant women who are pregnant nursing mothers young children. Advisory EPA-823-F-04-009.

UNEP. (2013a). Global mercury assessment 2013: sources, emissions, releases and environmental transport. UNEP Chemicals Branch: Geneva, Switzerland.

UNEP (2013b). Global mercury modelling: update of modelling results in the global mercury assessment 2013. UNEP G e n e va.h t t p s : / / w e d o c s. u n e p . org/bitstream/handle/20.500.11822/11440/ReportModellingupdateoftheGMA2013.pdf.pdf? sequence $=1$ \&isAllowed=y

UNEP. (2013c). Minamata convention on mercury. United Nations Environment Programme: Geneva, Switzerland Available: http://www.mercuryconvention.org/.

UNEP (2019). Global Mercury Assessment 2018. UN Environment Programme, Chemicals and Health Branch Geneva, Switzerland 62 pages. https://wedocs.unep. org/bitstream/handle/20.500.11822/27579/GMA2018. pdf?sequence $=1 \&$ isAllowed $=y$

United States Environmental Protection Agency (1997). Mercury study report to congress. Washington, D.C.: United States Environmental Protection Agency.

United States Environmental Protection Agency (2020a). EPA Mercury Portal. https://www.epa.gov/mercury

United States Environmental Protection Agency (2020b) What EPA is doing to reduce mercury pollution, and exposures to mercury https://www.epa.gov/mercury/what-epa-doingreduce-mercury-pollution-and-exposures-mercury

USGS (2019a). Mercury MCS 2019 Mercury. U.S. Geological Survey, Mineral Commodity Summaries, February 2019.

USGS (2019b). Mercury, ds140-mercu.xlsx. Geological Survey, Mineral Yearbook, 2019.

Vimercati, L., Santarelli, L., Pesola, G., Drago, I., Lasorsa, G., Valentino, M., Vacca, A., \& Soleo, L. (2001). Leukocytes in workers exposed to low levels of monocyte-macrophage system and polymorphonu- clear metallic mercury. Science of the Total Environment, 10(270), 157-163.

Vimy, M. J., \& Lorscheider, F. L. (1985a). Intra-oral air mercury released from dental amalgam. Journal of Dental Research, 64, 1069-1071.

Vimy, M. J., \& Lorscheider, F. L. (1985b). Serial measurements of intra-oral air mercury: estimation of daily dose from dental amalgam. Journal of Dental Research, 64, 1072-1075. 
Vimy, M. J., Luft, A. J., \& Lorscheider, F. L. (1986). Estimation of mercury body burden from dental amalgam computer simulation of a metabolic compartment model. Journal of Dental Research, 65, 1415-1419.

de Vries, D.J. Bakker (1998). Manual for calculating critical loads of heavy metals for terrestrial ecosystems -Guidelines for critical limits, calculation methods and input data . Report 166, DLO Winand Staring Centre, Wageningen, The Netherlands, TNO Institute of Environmental Sciences, Energy Research and Process Innovation, Den Helder, The Netherlands, 1998.

de Vries, W., Bakker, D., Sverdrup, H., Paces, T., Tipping, E. (2004). Effects-based approaches to assess the risk of heavy metal inputs to soils - overview methods and models. In: Workshop on critical limits and effect based approaches for heavy metals and persistent organic pollutants, H. Gregor, T. Spranger, F. Hörnerbach, (Eds). Umweltbundesamt, Berlin, Texte 5:98:125-224 ISSN 0722-186X.

Waldron, H. A. (1983). Did the mad hatter have mercury poisoning? British Medical Journal, 287, 1961-1972.

Wilhelm, S.M. (2001). Mercury in petroleum and natural gas: estimation of emissions from production, processing, and combustion. Office of Air Quality Planning and Standards EPA-600/R-01066, September 2001. Available at: http://www.epa.gov/ ORD/NRMRL/pubs/600r01066/600sr01066.Pdf, .

Wilhelm, S. M., Liang, L., Cussen, D., \& Kirchgessner, D. A. (2007). Mercury in crude oil processed in the United States. Environmental Science \& Technology, 41, 4509-4514. https://oi.org/10.1021/es062742j.
Windham, B. (2010). The results of removal of amalgam fillings: 60,000 documented cases. DAMS International. 23pp. www. thenaturalrecoveryplan.com, www.flcv.com/dams.

Wu, Q., Gao, W., Wang, S., \& Hao, J. (2017). Updated atmospheric speciated mercury emissions from iron and steel production in China during 2000-2015. Atmospheric Chemistry and Physics, 17, 10423-10433.

Yokoo, E. M., Valente, J. G., Grattan, L., Schmidt, S. L., Platt, I., \& Silbergeld, E. K. (2003). Low level methylmercury exposure affects neuropsychological function in adults. Environmental Health, 2, 8.

Zahir, F., Riziwi, S. J., Haq, S. K., \& Khan, R. H. (2005). Low dose mercury toxicity and human health. Environmental Environ Toxicol Pharmacol 2005, 20, 351-360 [PubMed: 21783611].

Zhang, Y., Jacob, D.J., Horowitz, H.M., Chen, L., Amos, H.M., Krabbenhofft, D.P., Slemr, F., St. Louis, V.L., Sunderland, E.M., 2015. Observed decrease in atmospheric mercury explained by global decline in anthropogenic emissions. Proceedings of the National Academy of Science of the United States of America 113: 526-531.

Zhao, H. L., Zhu, X., \& Sui, Y. (2006). The short-lived Chinese emperors. Journal of the American Geriatrics Society, 54, 1295-1296.

Publisher's Note Springer Nature remains neutral with regard to jurisdictional claims in published maps and institutional affiliations. 